Talvez até segunda-feira à noite, porque haveria maior repercussão e haveria mais tempo para se estudar a matéria.

O SR. DARCY AZAMBUJA - Não se trata de um assunto. de transcendência jurídica, mas tem grande importância na política local, muito grande mesmo. Por isso, êste Congresso não deve assumir a responsabilidade de decidir assim tão ràpidamente.

O SR. ALCIDES MENDONÇA LIMA - Não é o caso de. aprovação, porque pràticamente a matéria está aprovada.

O SR. PLAUTO AZEVEDO - Na Comissão!

O SR. ALCIDES MENDONÇA LIMA - E aqui no plenário somos quase que todos membros da Comissão.

O SR. DARCY AZAMBUJA - Não há nada aprovado; houve empate. A Comissão empatou!

O SR. ALCIDES MENDONÇA LIMA - E a presidência não tem o direito de desempatar?

O SR. PRESIDENTE - Em resumo, creio que está aprovada a sujestão do professor Darcy Azambuja, de adiarmos o debate pa-
ra outro dia. (Palmas).

(Tendo que se ausentar por alguns momentos, o senhor Salgado Martins deixa a presidência, sendo substituido pelo sr. Darcy Azam-
buja).

\section{COMPETENCIA PARA DECLARAR A INCONSTITUCIONALIDADE DAS LEIS}

\section{Dr. Alcides de Mendonça Lima}

Professor da Faculdade de Direito de Pelotas, da Universidade do Rio Grande do Sul.

\section{PRERROGATIVA AO PODER JUDICIÁRIO}

Já passou para os domínios das questões indiscutíveis a competência atribuida a um organismo fora do círculo do Poder Legislativo para declarar a inconstitucionalidade das leis. A celeuma levantada frente, à primeira manifestação neste sentido, nos Estados Unidos, no início do século XIX, quando MARSHALL criou a grande teoria, não mais persiste na atualidade. E' um cânone consagrado.

$O$ punctum dolens é que não se considera interferência estranha à competência do Poder Legislativo a declaração de inconstitucionalidade de uma lei, elaborada por aquêle Poder, por via de julgamento de órgão que lhe é alheio, quer êste órgão seja o próprio Poder Judiciário, por intermédio de uma de suas parcelas, quer seja um órgão especializado, autônomo, com função e atribuições definidas para êste fim. Assim sendo, apesar de ser o Poder Legislativo o autor da lei, não the é função própria negar aplicação à mesma, mas, sim, de um órgão a-parte, integrante ou não do Poder Judiciário, pròpriamente dito.

Por sinal que a apreciação da constitucionalidade - como ensina o enciclopédico PONTES DE MIRANDA - "deve recair em todos e quaisquer atos. Assim da Justiça, como dos outros órgãos do Estado, ainda aquêles que só exerçam função consultiva, pois a exigência formal da consulta implica a imprescindibilidade constitucional de exame ou de parecer (Os Fundamentos atuais do Direito Constitucional, pag. 399, n. ${ }^{\circ} 2$ ).

Si bem que, tanto na América - de onde proveiu o sistema -, como na Europa, se admita, hodiernamente, que um organismo fora do Poder Legislativo pode declarar a inconstitucionalidade de uma lei, há diferenças de organização entre os principais povos dos dois continentes. Na América, na maioria dos países, esta prerrogativa cabe 
aao Poder Judiciário, por intermédio de seus próprios órgãos. $\mathrm{Na}$ Europa, porém, esta prerrogativa cabe a órgãos especiais, denominados de "Tribunais de Inconstitucionalidade". Na República de Cuba, entretanto, é adotado o regime europeu (art. 182, da Constituição Federal). Inversamente, na Irlanda (art. 16), na Rumânia (art. 103) e na Grécia (art. 5), pelo menos em suas respectivas Constituições vigentes antes da última guerra, é adotado o sistema americano. Êste surto faz parte da chamada "Racionalização do Poder", após a guerra. de 1914, do qual se tornou o seu maior teórico o renomado prof. B. MIRKINE GUETZEVITCH. Entretanto, noutro ponto também se distanciam os modelos americanos e europeus, nas suas linhas mestras: Na América, ao ser declarada a inconstitucionalidade de uma lei, a mesma deixa de ser aplicada apenas ao caso concreto sub-judice, na Europa, porém, a declaração atinge visceralmente a própria lei, cassando-se a sua eficácia, para revogá-la. E’ mais forte, assim, a interferência.

No Brasil, desde 1.932, reeditado na Constituição de 1.946, que se acolheu uma fórmula original: Ser suspensa, pelo Senado Federal, a execucão, no todo ou em parte, de lei ou decreto declarados inconstitucionais por decisão definitiva do Supremo Tribunal Federal (art. 64). E' o que os norte-americanos chamam de "veto judicial”. A lei permanece, mas apenas com sua execução suspensa. Não há revogação de lei. De modo que, se o Supremo reformar sua jurisprudência, ao Senado cumpre revigorar o alcance da lei, cuja execução haja sido anteriormente suspensa, salvo se o próprio Poder Legislativo já haja elaborado outra lei, revogando aquela fulminada por julgado da mais alta Côrte.

Apesar de, na França, os textos constitucionais não incluírem o judicial control, a doutrina gaulesa entende possível êste contrôle mesmo para os países onde inexistam disposições constitucionais correspondentes (CFR. DUGUIT, "Traite",, tomo III, pag. 673). Êste foi, também, o mesmo ponto de vista que norteou os juizes, com MARSHALL na liderança, e os juristas norte-americanos, ao defenderem a idéia da superlegalidade constitucional, porquanto, na sua Constituição, não havia nenhum dispositivo que, diretamente, autorizasse a declaração de inconstitucionalidade pelo Poder Judiciário. A tal ponto chegou o pasmo pelo fato entre os doutos da época, que, segundo conhecida anedota, um inglês, sabendo da decisão da Côrte Suprema norte-americana, folheou, durante dois dias, a Constituição yankee, em procura do artigo que permitisse aquêle privilégio aos magistrados... ( $\left.{ }^{1}\right)$.

(1) O ́nico dispositivo da Constituição americana que enseja a possibilidade de ser uma lei declarada inconstitucional pelo Poder Judiciário, é o art. III, Seção 2.a

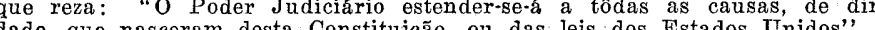

Desde que o juiz tenha profundas razões e forte convicção para declarar uma lei inconstitucional, êle não se pode eximir de sentenciar neste sentido, sendo considerado, por TOCQUEVILLE, como "o direito natural do magistrado", ou "o dever legal de todo juiz", no ensinamento de DICEY, não sendo lícito declinar dêsse dever, segundo COOLEY, pois a abstenção em o declarar inconstitucional impordo ta,ipso facto, em lhe afirmar a constélitos desta doutrina, em proclaSTORY. Tão rigorosos são os prosélitos desta dira a Constituição, que BRYCE entende ser "antes um dever do que um poder" - a declaraBRY ção de inconstitucionalidade. E na Comissăo da As ciac̃o de um tride Weimar, HUGO PREUSS combateu a idéia da criação de um tribunal constitucional específico, pois isso equivalia a tirar do juiz ordinário uma das suas mais importantes missões.

A todos os juizes se deve sempre recordar a frase incisiva e memorável do presidente da Côrte do Estado de Virgínia, nos Estados moráce do vantagem, a afirmativa de que, conforme Unidos, ao redà Constituição, a lei era igualmente obrigatória para todos os juizes: "Ainda quando a legislatura inteira tente saltar os todites, que o povo the traçou, eu, administrando a justiça pública do país concentrarei a autoridade investida nesta cadeira, e, apontando país, concentrarei a autoridade inves "A ne exta os confins de vosdo a Constituição, direi aos legisladores: "Aqui estão os confins de vosso poder; daqui não passareis!" Isso ocorreu antes mesmo do célebr voto voto de que, desde os tempos coloniais, impressionava os tribunais norte-americanos.

Esste atributo, portanto, está implícito na função dos membros do Poder Judiciário, isso é, dos juizes, pois, na lição de STORY, "o poder de interpretar as leis envolve, necessàriamente, a função de verificar se elas se conformam à Constituição, declarando-as vãs e inxificar se elas se conformam. Sendo a Constituição a suprema lei do subsistentes, se a ofendem. Sendo a Constituição a supres Estados país, em qualquer conflito entre ela e as leis, sejam estas dos Estados
ou do Congresso, é dever do poder judiciário aderir ao preceito, cuja obrigaçãa fôr predominante. Esta conseqüência resulta da própria teoria da Constituição dos governos republicanos; porque, de outra parte, os atos do poder legislativo e do executivo seriam de feito suparte, os atos do podé lis, não obstando as cláusulas. limitativas ou premos e incontrastáveis, não obstando as cándo-se tentar as usurproibitivas, que a Constituição encerrasse, podendo-se tentar as usurdio pações de caráter mais 


\section{O SISTEMA BRASILEIRO - 1.891 a 1.946}

Transplantando o princípio que a jurisprudência norte-americana formulara, com o beneplácito dos doutrinadores, mesmo em face de ausência de dispositivo expresso, a Constituição brasileira de 1.891 estabeleceu:

"Compete aos juizes ou tribunais federais processar "e julgar as causas, em que alguma das partes fundar a "ação, ou a defesa, em disposição da Constituição Fede"ral". (art. 60, a).

"Das sentenças das justiças dos Estados, em última “instância, haverá recurso para o Supremo Tribunal Fe"deral, quando se questionar sôbre a validade de tratados "e leis federais, e a decisão do TRIBUNAL do Estado "fôr contra ela". (art. 59, § $1 .^{\circ}, a$ ).

Na observação do imortal RUI BARBOSA, “ a redação é claríssima. Nela se reconhece, não só a competência das justiças da União, como a das justiças dos Estados, para conhecer da legitimidade das leis perante a Constituição" "Comentários à Constituição Federal Brasileira", coligidos por Homero Pires, vol. IV, pág. 133).

Estava, pois, consagrada a prerrogativa, que era atribuida a todos os tribunais, federais ou locais, que podiam discutir a constitucionalidade das leis da União, aplicá-las ou não aplicá-las.

Daí, certamente, a origem do art. $6 .^{\circ}$, da segunda Lei de Organização Judiciária do Rio Grande do Sul, de 1.925 , repetindo dispositivos da Lei n. ${ }^{\circ} 10$ de 1.895; "Os juizes e tribunais não aplicarão as leis e regulamentos manifestamente inconstitucionais". Qualquer que fôsse a inconstitucionalidade: Se ante a Constituição Federal ou. a Estadual, desde que manifesta.

De qualquer maneira, não havia, ainda, um artigo que, de modo mais categórico e expresso - em que pese à opinião do Gênio de Haya - dispusesse, na Constituição Federal, sôbre aquela função outorgada ao Poder Judiciário. Ainda mais. Não se prescreviam regras como deveria ser auferida a declaração de inconstitucionalidade.

Nota-se, entretanto, que, já na Constituição de 1891, quando se tratava do recurso que, posteriormente, seria denominado de "extraordinário", havia referência a TRIBUNAL do Estado (art. 59, $\S 1 .^{\circ}, a$ e $\left.b\right)$. Não era assim usada a expressão equivalente a juiz, como órgão singular do Poder Judiciário. O mesmo aconteceu na reforma de 1926, inclusive com a alínea $c$, do $\$ 10^{\circ}$ do art. 60 , que foi uma inovação. Na verdade, o Supremo Tribunal Federal tinha competência para julgar os recursos ordinários interpostos contra decisão dos juizes e tribunais federais nos casos do art. 60, sobre- tudo quanto à alínea $a$ - "as causas em que alguma das partes tudo quanto à alinea daço da Constituição Federal”. Sòm ação, eu 1934 na Constituicão de 16 de julho, apareceu, Sòmente em 1934, na Constitução de 16 dispositivo que conpela primeira vez, no ordenamento brasio e esboçado na Carta de 1891. Foi o art. 179, que prescreveu:

"Só por maioria absoluta de votos da totalidade dos "seus juizes, poderão os tribunais declarar a inconstitucionalidade da lei ou ato do poder público".

Ficavam abrangidos pelo artigo não só a lei, pròpriamente dita, no sentido estricto, como qualquer ato do poder público (Decreto, Regulamento, etc.).

No dispositivo citado, não só se concretizava a prerro No dambém se estabelecia o modo ou o "como" de ser a mesma utilizada.

As Constituições dos Estados-Membros, nascidos sob a égide daquel estatuto fundamental, repetiram, na quase totalidade, o princip princípio contido naquele artigo, mas com

ma, com reflexos na substância do mesmo. A da Paraíba se referiu, expressamente, aos juizes e tribunais (art. 66)

A do Paraná (art. 64), a de Minas Gerais (art. 53), a do Espírito Santo (art. 65), a de Santa Catarina (art. 61), a do Ceará pirito Sa) a de Maranhão (art. 77) e a do Rio de

(art. 49) a de Maranhào (art. 77 ) eder Judiciário.

mencionaram, genèricamente, o Poder Judiario. 57 ), a de Alagoas

A do Amazonas (art. 87, f), a de Goiaz (art. 57), a de Alagoas art. 75), a do Mato Grosso (art. 46), a de Pernambuco (art. 74) como atria do Rio Grande do Norte (art. 67)

buição própria da Côrte de Apelação.

A do Sergipe foi mais categorica, pois estatuín quente, à Côrção de inconstitucionalidade

te de Apelação (art. 81, $b$ ).

A do Piauí transplantou, pura e simplesmente, o texto da Constuicão Federal (art. 84).

A do Rio Grande do Sul num capítulo sui-generis sôbre "Co- A do Rio Granes", deu atribuicão expressa aos "juizes e tri ordenação de Poderes , deu Paraíba.

bunais" (art. 90, n. ${ }^{\circ} \mathrm{III}$, a), imitando, assim, a da Paraiba.

$\mathrm{E}$ as do Pará, São Panto e Bahia nada prescreveram a respeito.

Verifica-se, assim, que as Constituintes estaduais interpícta não diferentemente o artigo da Constituição Federal sobre a matéria, não havendo harmonia entre as diversas assembleias regionais, pois ou gumas subtraiam aos juizes singulares a prerrogativa, enquanto outras lha mente. 
O ato de 10 de novembro de 1937 , chamado de Constituição do
do Novo, no art. 68, repizou, quase na íntegra, Estado Novo, no art. 68, repizou, quase na íntegra, o art. 179 da

"Só por maioria de votos da totalidade dos seus juide lei ou Foi excluido ou ato do Presidente da República".

der público" por "ato do Presidente" e substituiu-se "ato do poA situação "ato do Presidente da República".

com precisão, se apenas o a mesma de antes. Não se esclarecia, - do Poder Judićán orgão colegiado - ou sejam os tribunais uma lei ou ato do poder público declarar a inconstitucionalidade de se o privilégio se esten da Rública, ou

zes singulares.

que regulou a cobrancra-les n. ${ }^{\circ}$ 960, de 17 de dezembro de 1938 , que regulou a cobrança executiva das dívidas fiscais - que, ainda vicional, proveiu da mesma fonte discrisção navembro de 1937 , Cr\$2.000,00, nas quais normalmente nas causas de valor inferior a a Fazenda é nas quais normalmente sòmente cabe recurso quando ver matéria constitucior Por conseguinte, mal" - art. 74, § único.

sentença do juiz não será conclue a parte vencida não recorra, a ria constitucional, não pria, dependendo de exame de a mesma em julgado por si próTribunal de Justiça ou, atualmente, de revisão por parte do nal Federal de Recursos, por force, também por parte do Tribucombinado com dito decreto-lei,

A Constituição Federal de 18 de Constituição Federal de 1946. art. 179, da Constituicão de 1934 ne setembro de 1946 reeditou o "Só pelo voto

poderão os tribunais maioria absoluta de seus membros lei ou ato do poder públicorar a inconstitucionalidade de er público".

Entretan-se, tão sòmente, o termo "juizes" por "membros". petência para declarar a inconstitucionstia a dúvida quantoà comder público. Apenas a inconstitucionalidade de lei ou ato do poou também aos juizes singulares sespeitado o quorum exigido, gressão doutrinária sôbre singulares se confere êste privilégio? A digressão doutrinária sôbre a matéria abrangerá as nossas três úl, pela identidade de fórmula e princípio consig-

blema. Na vigência de 1934 que deu lugar, inicialmente, ao procontrovérsias, na ausência de uma regra limitativa, que estabelecia posteriores Cartas Magnas nacionais. Desde que inexistia, no período de 1891 a 1934, qualquer norma restritiva, se tinha de admitir que prerrogativa era comum a todos os membros do Poder Judiciário, porquanto o silêncio importava em consagrar a regra geral

Entretanto, o sistema da carta de 1934 mudou o panorama da questão.

$\mathrm{O}$ ante-projeto da dita Constituição prescrevia: "Sempre que qualquer tribunal ou juiz não aplicar uma lei federal ou anular um ato do Presidente da República, por inconstitucional, recorrerá exofício e com efeito suspensivo para o Supremo Tribunal". $\mathrm{Na} \mathrm{Co}$ missão Constitucional, porém, foi apresentado substitutivo nos seguintes termos: "O pronunciamento de inconstitucionalidade de lei ou ato do Govêrno tem lugar SòMENTE pelo voto expresso da maioria absoluta dos juizes do Tribunal". Êste substitutivo veiu a transformar-se no art. 179 do texto definitivo (CFR. "A NOVA CONSTITUIÇÃO", Araujo de Castro, pag. 249).

A colocação do advérbio "sòmente", na oração do art. 179, influiu para alastrar as dúvidas. No substitutivo acima aludido, e mesmo se referia expressamente à competência do órgão que poderia declarar a inconstitucionalidade. Mas no texto definitivo, entendeu-se como traçando normas aos tribunais, quando, originàriamente ou por via de recurso, conhecessem de causas em que se discutisse a inconstitucionalidade de uma lei ou ato do poder público. Mas o estudo da gênese do art. 179 da Constituição de 1934 nos leva à conclusão de que o advérbio "só" dizia respeito à competência e não ao modo de funcioanmento do Tribunal, quando tivesse de apreciar causa em que fôsse declarada inconstitucional qualquer lei ou ato do poder público. A prova disso está na maneira diversa com que foi transladado o princípio para as Constituições estaduais, conforme discriminação que fizemos linhas atrás.

O mesmo acontecia com o texto do art. 96 do ato de 1937. Durante sua vigência, as antigas Constituições dos Estados-Membros deixaram de vigorar. Mas as Leis de Organização Judiciária foram esclarecedoras quanto à maneira do legislador estadual interpretar o mencionado art. 96, devendo ressaltar-se que ditas leis tinham de ser submetidas à aprovação do Presidente da República, que era o responsável pela elaboração do ato de 10 de novembro de 1937.

Vejamos a redação, neste ponto, das Leis de Organização Judiciária dos grandes Estados-Membros e do Distrito Federal.

- A Lei de Organização Judiciária do Estado do Rio Grande do Sul (Decreto-Lei n. ${ }^{\circ}$ 9, de 26 de fevereiro de 1940), que se seguiu à instituição do Estado Novo, assim prescrevia:

"Art. 6. ${ }^{\circ}$ - Os juizes e tribunais não aplicarão as leis e regulamentos manifestamente inconstitucionais. 
$\S 10^{\circ}$ - Só ao TRIBUNAL DE APELAÇÃO, por maioria absoluta de votos da totalidade de seus membros, cabe declarar a inconstitucionalidade da lei ou de ato do poder público.

$\S 2 .^{\circ}$ - Sempre que o juiz singular tiver de concluir pelo recoblico, remeterá inconstitucionalidade da lei ou de ato do poder público, remeterá o processo ao presidente do Tribunal, para o fím previsto no parágrafo anterior.

$\S 3 .^{\circ}$ - Se se tratar de câmara, igual procedimento incumbe ao seu presidente, que suspenderá o julgamento, quando verificar que o pronunciamento da câmara será no sentido da inconstitucionalidade.

A Consolidação das Leis de Organização Judiciária do Estado, tornada oficial pelo Decreto n. ${ }^{\circ} 544$, de 5 de junho de 1942 , alterou a redação do citado art. 1. ", substituindo "do poder público" por "do residente da República" e cancelou os $\$ \$ 20^{\circ}$ e 3.0 .

$E m$ diversos acórdãos, aquela Côrte julgou que sòmente se aplicava aquêle dispositivo quando se tratava de que somente se do Presidente da República; nos casos de leis estaduais ou municipais, tanto o juiz singular, como as câmaras isoladas poderiam declarar a inconstitucionalidade. Em todos os arestos, houve diversos votos vencidos, encabeçados pelo desembargador SOLON SOARES, atendendo a que o diploma, que alterou o texto originário da Lei de Organização Judiciária, não cumprira as formalidades do de creto-lei federal n. ${ }^{\circ} 1.200$, de 8 de abril de 1939 , regulador da admimistração dos Estados e dos Municípios. (JUSTIÇA, de Pôrto Alegre, vol. XIX, pag. 242, 244 e 268; vol. XXI, pag. 94 e 253; vol. XXII, pag. 341 ; vol. XXIII, pag. 470 ; vol. XXIV, pag. 157 ; vol. XXV, pag. 738).

A Lei de Organização Judiciária do Estado de São Paulo determina no art. $5 .^{\circ} \mathrm{n} .^{\circ} \mathrm{I}$, alínea $e$, relativa à competência do Tribunal de Apelação, sem que tratasse da matéria em dispositivo genérico como fez a do Rio Grane do Sul:

"Processar e julgar as argüições de inconstituciona-

lidade de Lei ou de ato do Presidente da República.

(Const. Federal - art. 96)"

$\hat{E}$ interessante verificar a remissão expressa à carta federal.

A Lei de Organização Judiciária do Estado de Minas Gerais prescrevia no art. 257 , n. ${ }^{\circ} 20$, ao tratar da competencia do Tribunal de Apelação, em Câmaras Reunidas:

"nos têrmos da Constituição, decidir sôbre a incons titucionalidade da lei ou atos do Presidente da Repú-
blica (art.96)".

Novamente, referência direta à carta federal.
A Lei de Organização Judiciária do Distrito Federal estatuía no art. 14, n. ${ }^{\circ}$ III, ao fixar a competência do Tribunal de Apelação iem sessão plena:

"decidir por maioria absoluta de votos da totalidade de seus membros sôbre a inconstitucionalidade da lei ou ato do poder público, no scasos de sua competência e nos que lhe forem remetidos pelas Câmaras, designado prèviamente, o relator".

Esta última é de suma importância, pois foi elaborada pelo mesmo poder e, possívelmente, pelos mesmos legisladores responsáveis pela carta de 1937. Entretanto, não fez a hipótese do feito subir até o Tribunal Pleno mediante remessa do juiz singular, mas, apenas, se o caso lhe competisse originàriamente ou lá chegasse por via de remessa de uma das Câmaras.

Isso demonstra, pois, que tanto em 1934, como em 1937, os legisladores estaduais, nos diplomas de sua competência, on o próprio legislador federal, para o Distrito Federal, na interpretação dos dispositivos das cartas federais, excluiam dos juizes singulares a prerrogativa para declarar a inconstitucionalidade de lei ou ato do poder público frente à Constituição Federal.

Com relação à Constituição de 18 de setembro de 1946, o estudo das Constituições estaduais divulgadas com mais profusão é deveras elucidativo, revelando o pensamento dos legisladores regionais sôbre o texto federal e como o transcrevemos para suas respectivas cartas. Diz a Constituição do Estado do Rio Grande do Sul, no art. 120:

"A inconstitucionalidade de lei ou ato do poder público só poderá ser declarada pelo voto da maioria absoluta dos membros do Tribunal de Justiça".

Fica excluída, assim, a competência dos juizes singulares e até das Câmaras, separadas ou reunidas.

Categórica é também a Constituição do Estado de Minas Gerais, no seu art. 70, n. ${ }^{\circ} \mathrm{I}$ : "Compete PRIVATIVAMENTE ao Tribunal de Justiça declarar, pelo voto da maioria absoluta de seus membros, a inconstitucionalidade de lei ou ato do Poder Público".

O advérbio de modo "privativamente" não deixa dúvidas quanto à competência conferida apenas ao Tribunal de Justiça, na plenitude de seus desembargadores.

A Constituição do Piauí estabelece: "Art. 80 - Surgindo alegação de inconstitucionalidade, a autoridade judiciária, perante quem correr o feito, verificará se pode proferir a decisão por outro fundamento. Se adotar a conclusão afirmativa, assim julgará, abstendose de apreciar aquela alegação. Caso contrário, remeteráa o processo $22-$ R. D. $-2.0 \mathrm{VGl}$. 
com a instrução que fôr requerida, ao Tribunal, para que se pronun cie a respeito da argüição.

E idêntico ao sistema preconizado pela citada Lei de Organização Judiciária do Estado do R. G. Sul, de 1940, acima transcrita.

A Constituição de Pernambuco repete, no art. 86, o texto federal, si bem que incluindo o dispositivo na secção referente ao Tribunal de Justiça e não nas disposições gerais do Poder Judiciário, subtraindo, assim, aos demais órgãos aquêle privilégio.

A Constituição de Paraná, entre os casos de competência privativa do Tribunal de Justiça, estatui no art. 68, n. ${ }^{\circ}$ IX: "declarar, pelo voto da maioria absoluta de seus membros, a inconstitucionalidade de lei ou de ato do poder público estadual ou municipal".

A Constituição de Alagoas prescreve na secção, relativa ao Tribunal de Justiça - art. 74: "Só pelo voto da maioria absoluta de seus membros, poderá o Tribunal de Justiça declarar a inconstitucionalidade de lei ou ato do poder público".

Já a Constituição do Ceará firma no art. 47: "O Poder Judiciă. rio negará aplicação às leis e resoluções contrárias à Constituição e leis federais e a esta Constituição", dispositivo êste constante das Disposições Preliminares do Capítulo que trata do Poder Judiciário.

A Constituição do Espírito Santo (art. 48, n. ${ }^{\circ}$ VI) e a Constituição de Goiás (art. 57, n. ${ }^{\circ} \mathrm{V}$ ) tratam da matéria no Capítulo referente ao Tribunal de Justiça.

A Constituição de Santa Catarina assim se expressa: Só pelo voto da maioria dos membros do Tribunal de Justiça poderá ser declarada a inconstitucionalidade de lei ou de ato do Poder Público" $($ art. 80). (2)

A Constituição da Bahia, e a Constituição de São Paulo silenciam a respeito, como, aliás, fizeram as anteriores, na vigência da Constituição Federal de $1934 .{ }^{(3)}$

Esta situação, portanto, das Constituições e Leis de Organização Judiciária dos Estados-Membros, quanto ao modo de interpretarem os dispositivos idênticos nas cartas de 1934, 1937 e 1946.

\section{A JURISPRUDENCIA E A DOUTRINA}

Temos, porém, de reconhecer que a jurisprudência, quer duran.te a Constituição de 1934, quer durante o ato de 1937, se mostrou

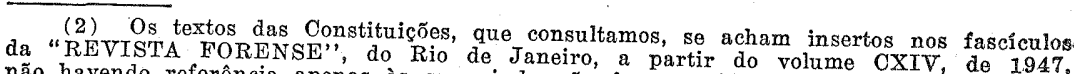
não havendo referência apenas às que ainda não foram publicadas. (3) E o recente Código de Organização Judiciária do Esticadas.
Sulo do Rio Grande do Sul, promulgado em 12 de Abril de 1950 pelo sr. Presidente da Assembléia Legislativa
do Estado, sem repetir os dispositivos dos diplomas similares que o antecederam, con signa no Art. 24, n. ${ }^{\circ}$ I, ao tratar da competência do Tribunal de Justiça, na compo tificando assim, o art. 120, da Constituicâa E Estadual, ou de ato do poder público", ra favorável à competência dos juizes singulares para declarar a inconstitucionalidade das leis. Interessante observar, por sinal, que, segundo os repositórios acusam, os próprios juizes singulares opunham resistência ao uso por êles mesmos daquela prerrogativa, declarando-se incompetentes e remetendo os atuos ao Tribunal de Apelação respectivo, que, por acórdãos de composição plena, deliberavam a favor da competência, devolvendo o processo ao magistrado de primeira instância. Vejam-se, a propósito, as seguintes decisões: Sentença do Juiz Martins de Oliveira, da Comarca do Patrocínio, Minas Gerais, de 22 de outubro de 1934, in "REVISTA FORENSE", vol. 65, pag. 170; Acórdãos de Tribunal de Justiça de São Paulo, de 10 de marco de 1937, in "REVISTA FORENSE", vol. 70, pag. 548; de 25 de novembro de 1936, in "REVISTA FORENSE", vol. 79, pag. 351; do Tribunal de Justiça de Minas Gerais, de 27 de janeiro de 1937 , in "REVISTA FORENSE", vol. 70, pag. 114.

E o próprio Supremo Tribunal Federal, por acórdão unânime de 11 de novembro de 1943, julgou, na sua alta sabedoria, que "cabe aos juizes de primeira instância apreciar a argüição de inconstitucionalidade da lei, com recurso para instância superior, a qual cabe o pronunciamento definitivo", sendo relator o eminente Ministro ANIBAL FREIRE ("REVISTA FORENSE", vol. 99, pag. 83).

$\mathrm{O}$ único julgado, que aparece contra a competência dos juizes singulares, é de lavra do Tribunal de Justiça da Bahia, tomado, nesta parte, por unanimidade de votos, datado de 8 de setembro de 1940 ("REVISTA FORENSE", vol 86, pag. 151).

Este aresto mereceu meticuloso e bem lançado estudo do $\mathrm{dr}$. VICENTE CHERMONT DE MIRANDA, em artigo publicado in "REVISTA FORENSE", vol. 92, pag. 582, apoiando as conclusões sôbre a questão.

$\mathrm{Na}$ atualidade, à luz da vigente Constituição Federal, sòmente encontramos um pronunciamento, assim mesmo de Juiz singular considerando-se competente, em fundamentada e brilhante sentença (Juiz de Direito ALFREDO GUIMARÃES CHAVES, da Comarca de Piui, Estado de Minas Gerais, in "REVISTA FORENSE", vol. 120 , pag. 208)

Já em relação à doutrina - que se aplica às três últimas Constituições, pela identidade de princípios e quase unidade de redação, predomina a idéia que assegura o privilégio apenas quanto aos tribunais, na plenitude de sua composição.

PONTES DE MIRANDA, com sua autoridade de mestre nos mais variados ramos da ciência jurídica, ensina, estudando a Constituição de 1937, que, para a declaração da inconstitucionalidade de uma lei ou de algum ato dos Podêres Públicos perante a Constituição de 1891, não é preciso que se componha a maioria absoluta 
favorável à constitucionalidade. O juiz singular, portanto, pode decretar a inconstitucionalidade de leis em conflito com a Constituição de 1891. MAS JÁ EXIGE O QUORUM CONSTITUCIONAL EM SE TRATANDO DE DISPOSIÇÃO DA CONSTITUIÇÃO DE 1934, PORQUE ESTA ASSIM O REGULA. (CFR. "Comentários à Constituição Federal”, 1937, vol. III, pag. 47). Êste ponto de vista é reiterado in "Comentários à Constituição Federal", 1946 vol. IV, pag. 180).

O ilustre professor e sociólogo PEDRO CALMON escreve: " $\mathrm{Na}$ Constituição em vigor (1946), a função de declarar a inconstitucionalidade de lei ou até do poder público - é dos TRIBUNAIS pela maioria absoluta de seus ministros (art. 200)" ("CURSO de Teoria Geral do Estado", 3. a Edição, pag. 275). Melhor seria a palavra "membros", pois ministro é têrmo usado apenas para designar os componentes do Supremo Tribunal Federal e Tribunal Federal de Recursos e, impròpriamente, do Tribunal Superior de Trabalho.

O insígne TEMISTÓCLES CAVALCANTI, nos seus comentários à Carta de 1946 - apesar de serem mais de ordem administrativa do que constitucional em tôda a obra, dada a especialidade do festejado autor inicia o estudo do art. 200 do seguinte modo: "Como se vê da redação do texto, os Constituintes partiram do pressuposto indiscutivel de que a declaração de inconstitucionalidade estaria na técnica e na competência normal dos Tribunais" ("A Constituição Federal Comentadá", vol. IV, pag. 201).

Entretanto, já CARLOS MAXIMILIANO, com o renome que o aureola como um dos nossos mais perfeitos constitucionalistas, sustenta o contrário: "Das palavras transcritas, já se infere que o art. 200 resolve apenas uma questão relativa ao quorum para o julgamento; não colima fixar COMPETENCIA. O preceito exarado no estatuto brasileiro não é novo; abrolhou na prática norteamericana, qeu impôs a exigência de maioria absoluta; foi além, reclamou o comparecimento de TODOS os membros do pretório julgador da inconstitucionalidade (the full bench). Por aí já resulta claro que trata de questão de OUORUM; não - de COMPETENCIA. (Omissis). A inconstitucionalidade pode, e DEVE, ser declarada logo, na PRIMEIRA INSTÂNCIA". " "Comentários à Constituição Brasileira”, 1946, vol. III, pag. 265, n.o 636).

$\mathrm{Na}$ mesma trilha, segue o preclaro EDUARDO ESPINOLA, nos seus consisos comentários à carta de 1946: "É Inquestionável que qualquer juiz ou tribunal pode negar aplicação a uma lei inconstitucional; mas a declaração de inconstitucionalidade, que fulmina a lei, no regime da Constituição, como também acontecia - em 1934, é a do Supremo Tribunal Federal". ("A Nova Constituição", pág. 37).
$\mathrm{Na}$ sua excelente monografia " $\mathrm{O}$ contrôle jurisdicional da constitucionalidade das Leis", o festejado jurista C. A. LUCIO BITENCOURT filia-se à corrente que aceita a competência do juiz singular, sustentando: "Poderá, porém, o juiz singular de $1 .^{\text {a }}$ instância dizer da inconstitucionalidade? De acôrdo com o nosso ponto de vista, anteriormente expresso, de que êsse poder é inerente ao exercício da função jurisdicional, é óbvio que a resposta afirmativa se impõe" (fls. 36 e 46 ).

Aliás, ao ser discutida, na Assembléia Nacional Constituinte, Constituição em vigôr, o deputado RAUL BARBOSA ofereceu, a Conteńrio, a emenda n. ${ }^{\circ} 498$, sôbre o então artigo 190 do projeem plenário, a emenda n. 498, sobre o então artigo 190 divo je to primitivo, que se converteria no art. 200 do texto definitivo, declarando aquele parlamentar o seguinte: "O dispositivo do art 1950 do projeto se aplica, indistintamente, ao Supermo Tribunal Fe1950 do projeto se aplica, inde do país e a atribuição de declarar a deral e aos demais é reconhecida até aos juizes singuläres". ("A inconstitucionalidade e reconhecira de 1946", do Desembargador JOSÉ DUARTE, vol. III, pag. 369).

Observa-se, assim, sem dificuldade, que há duas correntes, cada uma perfilhada por vultos eminentes, de inconteste prestígio, tomando posição diferente em tôrno do problema.

\section{A INCOMPETENCIA DOS JUIZES SINGULARES}

Nesta parte, a questão não pode ser focada e estudada à lut dos princípios que sustentaram a teoria norte-americana, que nos dos a teoria alienígena apenas fixou, como de serve de paradigma. A teoria alienigena ãcen que ao Poder Jucorrência de superlegalidade da Constituição, de uma lei, sempre diciário é lícito declarar a inconstitucionalidade de uma lei, sempre que esta viole ou transgrida um preceito do estatuto fundamental.
Entretanto, isso não quer dizer que esta prerrogativa deva ser obriEntretanto, isso nfida a todos os juizes e tribunais, como inerente gatòriamente conferida a todos os juizes e tribunais, como deve ser usaà própria competência do Poder Judiciario. Como destriçóes da esta prerrogativa, seu alcance seus limites, suas restriçóes podem ser estabelecidas normas de acordo com a indole, com os

costumes, com as tendências, com as necessidades e com as ação.
liaridades de cada povo, de conformidade com sua organizaça

Daí o acêrto da afirmação de HARVEY WALKER, quando, ás demonstrar que os assuntos de importância fundamental, próapós demonstrar que os assuntos no tempo e no espaço, esclarece prios das Constituços, derminado assunto costuma, nos que, ainda mesmo quando um determinado as legislatura ordinária, é ineoutros países ou Estados, ser deixado à legislatura ordinaria, e inegável que, para o país ou Estado que o incluíu na sua Carta Polrgavel que, a ser matéria constitucional, afastada da competên- 
cia legislativa ordinária e deferida à soberania do povo". (apur LÚCIO BITENCOURT, op. cit. pág. 59-60).

O essencial é atribuir ao Poder Judiciário aquela competência. Certas parcelas, porém, dêste poder podem ficar excluidas ou ter sua iniciativa restringida, concedendo-se a outro órgão também do Poder Judiciário, a palavra final sôbre a controvérsia. Isso em nada desfigura o sistema, pois, de um modo ou de outro, é semper o Poder Judiciário o competente para invalidar os efeitos da lei impugnada no caso concreto.

Na Constitnição de 1891, na ausência de dispositivo expresso, sôbre a matéria, prevalecia o regime norte-americano, de ampla competência, abrangendo todos os órgãos do Poder Judiciário singulares ou colegiados.

Aí, então, na falta de uma norma limitativa de competência de certos órgãos, se tem de considerar, ainda com BRYGE, "que êsse dever incumbe, não menos do que à Suprema Côrte Federal, em Washington, ao mais humilde tribunal de qualquer Estado, logo que perante êle se pleiteie feito que levante a questão. Quando, portanto, como às vêzes até nos Estados Unidos acontece, falam na Suprema Côrte como guarda da Constituição, apenas se quer dizer que é o tribunal de última instância, ao qual se podem levar os processos, por envolverem questões constitucionais. Mas as funções da Suprema Côrte são as mesmas em gênero que as de todos os outros tribunais, federais ou dos Estados. É obrigação dela e dêles aplicaram a lei; e onde quer que um tribunal, seja um tribunal de primeira instância, no Estado, ou o tribunal federal de instância mais alta, encontrar uma lei, de autoridade inferior, contrariando uma lei de autoridade superior cumpre-lhe rejeitar a primeira, como não lei, e executar a segunda".

Sòmente por têrmos expressos, se pode firmar a competência de determinado órgão do Poder Judiciário para, com exclusividade, declarar a inconstitucionalidade de uma lei, subtríndo-a, portanto, àquêles que não foram contemplados com o privilégio. A matéria continua contida dentro dos princípios doutrinários e teóricos, mas apenas situada dentro da esfera de certo órgão. De qualquer forma, é sempre o Poder Judiciário a agir, si bem que diminuida a ação de certos órgãos, quais sejam os juizes singulares. Na falta desta exceção, consideram-se todos os órgãos - singulares e colegiados - como competentes para declarar a inconstitucionalidade de uma lei, com fôrça definitiva, sujeita apenas aos recursos voluntários cabíveis para instância superior.

Para ser usada a faculdade outorgada ao Poder Judiciário, de suma importância individual e de grandes reflexos sociais e políticos, na coletividade, é necessário que o magistrado aja com cautela, com prưdência, com convicção, pois qualquer dúvida afasta a possibilidade de ser uma lei declarada inconstitucional, segundo princípio assente entre os mestres. A presunção milita sempre a favor da validade de uma lei, como emanação da soberania popular, representada pelos membros do Poder Legislativo. Para popular, reper éra como válida, não é preciso prerrogativa especial alguma, de modo a ser subtraído o privilégio a qualquer órgão do Poder Judiciário. Quando, porém, se trata da outra hipótese, de ser declarada a inconstitucionalirén, pois, neste caso, há um dade de uma lei, a situação e ato do Poder Legislativo, sendo êste pronunciamento contrário ao ato ho Podrado, de haver violado a acusado, em ultima análse, de hem de agir com firmeza, eviConstituição. Nesta emergencia, se tem de agir comas e correções, tando-se que a atividade do Congresso sofra censuras e correçóes, "que não sejam fruto de espírito amadurecido e oriún.

gão que apresenta mais autor náo deve aplicar uma lei que, na sua

Se, em tese, todo o juiz náo deve aplicar uma tigação, seja inupinião, depois de profunda reflexa por si mesma, independente de a decisão do magistrado subsista por si mesma, independente de "qualquer revisão ou reexame por um tribunal superior, mesmo que a parte prejudicada com a sentença se haja conformado com a mesa ño utilizando do recurso cabível ,tentando a reforma da ma, não se jullou contra seus interêsses, ou se não é um dos cadecisão que julgou contra seus interêsses, ou se não é

sos em que, taxativamente, a lei pror uma controvérsia, êle aplicará

Quando um juiz tem de julgar uma controvérsia, êle Se não a ou não ao caso concreto a norma invocada pelas partes. Se não a aplica, é por um dos seguintes motivos: Ou a norma invocada, impertinente, imprópria, incabível para a espécie; ou a norma, ampertinente, impróna está maculada com o vício de inconsaparentemente adequada, está maculada então êle deixa de aplititucionalidade. Nubmeter a seu império o caso em debate, tanto que ca-la, dexa de sub do preceito nela inserto. Deixou, portanto, não a soluciona à luz do preitoñ por entender que a mesma de cumprí-la, negando-lhe aplicação, por entender que a mesma transoride o estatuto fundamental. Foi assim mantido o pricípio trantrinário e político de que nenhum juiz deve aplicar uma lei que, udoutrinácio e poltico de que nen da prerrono seu ponto de vista, seja inconstitucional a gativa inerente ao Poder Judiciário. Haveria falha do regime se o juiz devesse sempre aplicar a lei, mesmo que, no seu entendimento, juiz devesse sempre aplicar a lal, sòmente podendo o tribunal invaliá a ce o caso até lá chegasse por via de recurso. lidá-la, se o caso até lá chegasse juiz deixa de aplicar a lei, mas a sua cia năo vai até esse ponto. O juiz deixa de aplicar ância superior.

Ná de ser, obigatonto a juirmativa do orande

Não é procedente, portanto, a afirmativa do grande obrigar os 
juizes singulares a aplicar leis inconstitucionais, o que lhes subtrairia a independência e tornaria sem valor o princípio da separação de podêres e a supremacia da lei constitucional (REVISTA FORENSE, vol. 67, pag. 348).

O privilégio, portanto outorgado ao Poder Judiciário - inclusive aos juizes singulares - pode sofrer restrições, impostas pelas Constituições. E o que acontecia, por exemplo, com a Constituição Austríaca de 1934, que, expressamente, proibia ao juiz singular considera uma lei contrária à Constituição, desde que publicada com observância das formalidades constitucionais.

Para que a manifestação judicial tenha mais ou menos valor, a Constituição pode exigir certas cautelas, quer estatuíndo que apenas os tribunais colegiados são competentes para declarar a inconstitucionalidade, quer estabelecendo um quorum especial, dentro dos citados órgãos, para ser determinada a inconstitucionalidade. Pode, assim, excluir do juiz singular a faculdade de tornar-se o seu julgamento definitivo, se não houver recurso do vencido. $O$ juiz não perdeu sua prerrogativa. Usou-a, tanto que deixou de aplicar a lei, contra a qual foi argüida a inconstitucionalidade, ou, então, êle próprio assim considerou, mesmo no silêncio das partes. Um único requisito, porém, a Constituição estipula: Que tal decisão seja revista, reexaminada, reestudada por um órgão superior, afim de não ficar aquela decisão como um virus a corroer, lentamente, o prestígio da lei, com possibilidade de alastrar-se, causando grave dano à estabilidade das instituições jurídicas.

Não se compreenderia, aliás, porque tanto rigor com os julgamentos nos tribunais colegiados. Se, no julgamento de uma apelação, é suscitada uma questão de inconstitucionalidade de uma lei, considerada procedente, os três desembargadores reunidos no Tribunal de Justiça do Rio Grande do Sul, por exemplo —, não podem decidir sôbre a matéria: Têm de remeter o feito para Tribunal Pleno. $O$ mesmo pode acontecer, com maiores proporcões e absurdo, se se trata de um caso de competência das Câmaras Reunidas - que podem funcionar com 7 membros no Rio Grande do Sul, num total de 16. Ainda mais. No próprio Supremo Tribunal Federal, uma turma, de cinco membros, não pode declarar uma lei inconstitucional, tendo de ser convocado o Tribunal Pleno, ou seja com seus 11 ministros. ( $\left.{ }^{4}\right)$

(4) Segundo jurisprudência dominante, não é preciso que estejam presentes todos Si houver número para o funcionamento do Tribunal Pleno, a inconstitucionalidade não. será declarada se, entre os presentes, não se manifestarem juizes que, somados, formem a maioria absoluta da composicãa total contra a totalidade da lei (CFR. REVISTA DH Dunal de Justica de Minas Gerais, de 6 de novembro de 1947 , confirmado, por unanimidade, pelo Supremo Tribunal Federal; Tribunal de Justiça do Rio Grande do Nor te; Tribunal de Justiça do Distrito Federal; Tribural de Justiga do R. G. do Sul
Na Assembléia Nacional Constituinte de 1946, o egrégio professor ELOY JOSÉ DA ROCHA, deputado federal pelo Rio Grande do Sul, defendeu a idéia de que o quorum deveria ser, não apenas de do Sul, defendeu a mas de dois terços dos votos da totalidade dos membros dos tribunais. Esta proposta foi combatida pelo culto mrefor professor pelo Estado de S. Paulo, sob o fundamento de que a exigêncquivaleria à impossibilidade de decisões, porque os tribunais cia equivaleria a impossibe, com metade e mais um de seus juizes funcionam, habíval obter sempre dois terços, nem mesmo para as não sendo possivel obter sempre dois ţ̧oria requerida. A êsses simples votações, quanto mais para a maioria requerida. A êsses argumentos, opoz reparos valiosos o douto desembargador JOSÉ DUARTE, ao momentar a discussão parlamentar: "A regra não pode ser aquela mencionada por MÁRIO MASAGÃO. Não é, pelo menos, no Distrito Federal, onde o Tribunal conta, sempre, com lo menos, no Distrito Fe resto, o dever do juiz é comparecer, quando o quorum legal. De restó a prioristicamente, argumentar com o convocado, e não se podera aprioristicamente, argumentar com o magistrado faltoso ou presumir que êle se esquive à sua obrigação precípua" ("A Constituição Brasileira de 1946", vol. III, pag. 370)

A sugestão do representante gaúcho foi a mesma do conspíe brilhante jurista e parlamentar JOÃO MANGABEIRA, ao constituição de 1934, em sucessivos artiglosar o ante-projeto. Ca Constituiçádo dambém, a necessidade da gos na imprensa carioca, sustentando, também, a necessidade da votação ser por dois terços e não sòmente por maioria absoluta, para afirmar que equêle trabalho fôra "previdente e sábio" ao estabelecer o quorum para as votações (CFR. "Em tôrno da Cons" tituição", vol. 117).

Nos Estados-Unidos, há uma grande aversão pelos julgamentos chamados "five to four", para a declaração de inconstitucionalidade. No Estado de Ohio, imitado pelo de Dakota, a inconstitucionalidade sòmente pode ser declarada se votarem, no mínimo, todos os juizes menos um. Por esta razão, o citado JOÃO MANGABEIRA adverte que "as decisões de inconstitucionalidade por GABEIRA advertivado os maiores clamores públicos e os mais inum voto tem mo mo cit. pag. 115 tensos protestos dos centros cultura o mesmo autor: "Para que a dee 116). E mais adiante, escreve o mesmo a mereça, em caso de tacisão desse da Naça, é preciso que o voto de manha gravidade, óche dentro da rauma maioria respeitável assegure a certeza de que, dentroilidade humana, dúvida não pode haver sôbre a juridicidade do julgamento supremo. Sòmente assim o aresto se imporá à condo julgam a dignidade do protesto nos outros dois ciência nacional, calando a dignidade do protestade da Justiça. Ta Podêres, emudecidos e submissos ante a majestade da Justiça. Tal
fôrça não terá jamais a decisão por um voto. Diante da dúvida 
que salteia e divide a própria Côrte, não há de ser ao palpite de 'uma vontade, ao imprevisto de um acaso, ou ao inopinado de uma surprêsa, que deverá ruir por terra a lei votada e sancionada pelos Poderes eletivos, e que ainda no Tribunal encontrou a quase maioria de seus membros para sustentá-la e defendê-la. Em casos tais, diante do Tribunal cindido meio a meio, prepondere a lei, oriunda dos Poderes "que, eleitos nas urnas, representam a Nação" (op. citã. pag 117 a 118).

O que dizer-se, assim, de uma decisão proferida por um só cénebro e uma só vontade! Haveria de modo muito mais grave, o perigo dos "efeitos maléficos de uma decretaço do mais grave, o pedade baseada em simples de uma decretação de inconstitucionaliLÚCIO BITENCOURT, maioria eventual", como adverte, ainda de 1946 a cigido pela Carta da 1946 na composição dos Tribunais para que possa ser fulminada uma lei ante à Constituição. (op. cit. pag. 51). Pelo fato de ficar circunscrita ao caso concreto, nem por isso deixará de prevalecer, se não houver recurso, tendo de ser cumprida e executada, dendo exigir até mesmo, tendo de ser cumprida e executada, podendo exigir, até mesmo, a colaboração efetiva do Poder Executivo, que, com sua atividade, ainda prestigiará o julgado, de procomo juiz: E' a natureza do órgão que interessa.

Pelo fato de se afirmar que a decisão do juiz fica sujeita a recurso por parte do litigante vencido pela mesma e que, se êle não o fizer, não haverá prejuízo, o mesmo se poderia alegar em relação aos julgados dos tribunais suscetíveis de recurso para instância superior (v. g. Embargos, Revista ou Recurso Extraordinário). Na declaração de inconstitucionalidade, o interêsse social sobreleva o interêsse particular dos litigantes. Mais do que a lesão que se possa praticar ao direito de uma das partes, acham-se a lesão se possa praticar Poder Legislativo e das partes, acham-se a lesão à própria lei, ao oder Legislativo e à ordem jurídica constituida.

Se, na verdade, a Constituição não autoriza, expressamente, o recurso ex-ofício, é porque não se trata de um recurso, no seute, o técnico processual. ' $E$ ' de uma obricacão um recurso, no seu sentido remeter os autos à instância obrigação imposta ao juiz, que deve ao concluir pela inconstancia superior, fundamentando sua decisão, ao conclur pela inconstitucionalidade de uma lei. Se o Tribunal rejeita a argüição, dentro do quorum constitucional, o processo baixará ao juiz, para, então, ser julgada a causa à luz da norma impugnada; se o Tribunal acolhe o ponto de vista do juiz, a causa ficará, então, julgada, para o fim de não ser aplicad juiz, a causa ficará, considerada inconstitucional.

Da mesma forma, a Constituição não indica o modo como deve agir uma parcela dos Tribunais, para endereçar o feito para Tribunal Pleno. Isso é matéria pertinente a uma lei ordinária espe- cial, da União, ou às Leis de Organização Judiciária dos EstadosMembros. Implicitamente, a Constituição exige a remessa por parte de uma turma ou câmara para o Tribunal Pleno respectivo, sem precisar o modus faciendi, as formalidades, as diligências a serem cumpridas, como não caberia num estatuto fundamental. Firmado o princípio, cumpre ao legislador ordinário traçar as regras para concretizá-lo. Assim sendo, com mais razão, exige a Carta Magna, implicitamente, que o juiz singular faça remessa dos autos para o tribunal hieràrquicamente superior, de acôrdo com a natureza da causa (Tribunal de Justiça ou Tribunal Federal de Recursos, na justiça comum; Tribunal Regional do Trabalho ou Tribunal Superior do Trabalho, na justiça do trabalho; Tribunal Eleitoral ou Tribunal Superior Eleitoral, na justiça eleitoral; Conselho de Justiça militar ou Superior Tribunal Militar, na justiça militar). A maneira como deve proceder o juiz singular, cumpre, conforme já dissémos, à lei ordinária estabelecer. Mas, na ausência de texto expresso, devem ser adotadas as regras relativas aos recursos ex-oficio (v. g. Decreto-lei n. ${ }^{\circ}$ 960 , de 17 de dezembro de 1.938 , ou a apelação prevista no art. 822 e $\S$ único do Código do Processo Civil), pois o mais importante é resguardar a pureza do princípio constitucional, independente do modo de ser concretizado na realidade.

E LÚCIO BITENCOURT - cujo livro foi dado à publicidade na mesma ocasião em que lançamos esta tese na "REVISTA FORENSE", não conhecendo um, portanto, o trabalho do outro, antes da divulgação de cada trabalho - entende, também, ser "de tôda a conveniência a regulamentação da matéria, estabelecendo-se, pelo menos, a obrigatoriedade de recurso ex-ofício para os tribunais, sempre que o juiz decidir pela existência da incompatibilidade entre a lei e a Constituição" (op. cit. pag. 41). Enquanto, porém, não houver esta regulamentação, aquêle autor, coerente com sua opinião antes manifestada, considera que a decisão do juiz singular pode constituir coisa julgada entre as partes, "desde que não sejam usados contra "ela opportuno tempore os recursos cabíveis" (loc. cit.).

$\mathrm{O}$ intuito do legislador constituinte - desde 1.934 - foi outorgar competência aos tribunais colegiados, como órgãos de segunda instância. Assim sendo, um órgão de $1 .^{\mathrm{a}}$ instância, mesmo colegiado - como as Juntas de Conciliação e Julgamento, da Justiça de Trabalho - não tem competência para declarar a inconstitucionalidade de uma lei. Si bem que um tribunal seja todo o órgão colegiado, o costume e a tradição têm usado aquêle têrmo para designar um órgão de segunda instância, isso é, superior a um singular ou mesmo a um coletivo, mas que, normalmente, seja de primeira instância. Os tribunais sòmente excepcionalmente são órgãos de primeira instância, nos casos taxativos, expressos (ação rescisória; alguns man- 
dados de segurança; conflitos de jurisdição, etc.). O seu normal é serem órgãos de segunda instância, nos quais os feitos chegam via de recurso.

Nos léxicos especializados, encontramos as seguintes definiçóes de Tribunal: " $E$ ' a sede do juiz, ou o lugar onde se faz justiça e,oes ordinário, se aplica, hoje, AOS JUIZES COLETIVOS OStiça e, de FUNCIONAM JUNTOS, como As Relações do Império" (TEI363). "Corpo de juizes, "Vocabulário Jurídico", ed. 1.883, pág. (Corpo de juizes que se reunem para julgar, cumulativamente, exercendo jurisdição comum" (PEDRO NUNES, "Dicionário de Tecnologia Jurídica", ed. de 1.948, pag. 593). E as Relaçôes do Império, citadas pelo grande mestre, como exemplos, eram óroãos de segunda instância.

No mesmo sentido, a lição do erudito LOPES DA COSTA "Os. juizes singulares são subordinados ao Tribunal (sôbre juizes)" (DIREITO PROCESSUAL CIVIL, vol. I, pag. 171, pag. 124).

O notável CASTRO NUNES assim define aquêle têrmo: "Juízos - emprega-se geralmente para designar o órgão de primeira instância, entre nós exercida, em regra, por magistrados singulares; tribunais é a denominação que se reserva aos corpos juidiciários, coletivos, em regra de instância superior". (Teoria e Prática do Poder
Judiciário", pag. 84, n. 5 ).

Não há demérito algum para os juizes singulares em lhes sersubtraida a prerrogativa concedida, privativamente, aos tribunais superiores $\left({ }^{5}\right)$. Tanto o seu julgamento se reveste, aos tribunais. que bastou um juiz, da mais humilde comarca ou têrmo, ter dúvidas. sôbre a constitucionalidade de uma lei, entendendo-a violadora do estatuto fundamental, que já se exige, automáticamdo-a violadora do. estatuto fundamental, que já se exige, automáticamente, o pronunciamento do tribunal superior, na plenitude de sua formaçẫo. Isso* demonstra que a opinião isolada de um magistrado, mesmo modesto. em suas funções, tem fôrça para provocar a manifestacão modesto bunal pleno a que se acha subordinado. O seu veredictum não triprestígio para prevalecer por si mesmo; mas tem prestígio para, independente da vontade das partes, suscitar julgado de tribunal superior, no seu conjunto.

O que se viza, tão sòmente, é resguardar a estabilidade da ordem jurídica constituída, cuja validade se presume, evitando-se que possa ser abalada de modo inseguro e duvidoso. Se houver, porém,

(5) Tanto valor se dá $\grave{a}$ composição natural dos tribunais, que o Regimento In terno do Supremo Tribunal Federal (art. $87, \$ 22^{\circ}$ ) veda a convocaça dos desembartrata de resolver uma preliminar de inconstitucionalidade formarem quorum quando se normais dos ministros da mais alta Côrte. Isso demonstra a preoserem os substitutos julgamento sôbre a matéria como o resultado dos verdadeiros componentes do torgãa o mecessidade de uma correção, que a mesma se origine num cenáculo judiciário, onde seus membros, individualmente e pelo que representam no seu todo, imponham mais respeito, mais acatamento, mais obediência, não só pelo tirocínio na arte de julgar, como pela cultura e pelas virtudes que hajam apresentado, no decorrer da judiciatura, permitindo-lhes chegar aos cumes da carreira.

\section{O N C L U S Ô E S}

A) Ao Poder Judiciário deve competir a declaração da inconstitucionalidade das leis ou ato do poder público;

B) As Constituições de cada Estado podem prescrever normas próprias para o uso daquela prerrogativa, segundo a mentalidade, as tradições e condições sociais e jưrídicas do povo;

C) Não viola o princípio fundamental a concessão do privilégio apenas a alguns órgãos do Poder Judiciário, excluída a competência de outros;

D) Se, na vigência da Constituição de 1.891 , por ausência de dispositivo expresso subtraíndo a competência aos juizes singulares, a outorga do poder declarativo era geral, abrangendo todo e qualquer órgão do Poder Judiciário, o mesmo não aconteceu nos regimes das cartas de 1.934 e 1.937, como também agora não sucede, quando a competência para declarar a inconstitucionalidade é privativa dos tribunais como órgãos colegiados;

E) os juizes singulares não ficam obrigados a aplicar uma lei que, no seu entender, seja inconstitucional. Mas, nesta hipótese, deverão remeter os autos com sua manifestação devidamente fundamentada ao tribunal superior, conforme a natureza da causa (Tribunal de Justiça; Tribunal Federal de Recursos; Tribunal Regional Eleitoral; Tribunal Regional do. Trabalho, etc.).

F) Enquanto não fôr elaborada uma lei federal estabelecendo a forma processual daquela providência, deverão ser aplicadas, por analogia, as regras referentes aos recursos exx-ofício, si bem que não haja, no caso, pròpriamente um recurso, no sentido técnico;

G) O Congresso deverá sugerir ao Parlamento Nacional a elaboração de uma lei que regule a matéria, traçando normas uniformes para todo o território nacional.

Pelotas, 25 de maio de 1.950. 


\section{A N E X O}

OBSERVACIAO: - Depois de elaborado e datilografado êste trabalho, obtivemos o texto de tôdas as Constituiçôes estaduais, contidas na obra "Sistema Constitucional Brasileiro", do autoria de berto B. Magalhães edicão de A. Colho Brano, , de autoria de Roa seguir, os dispositivos que tratam na relac̃ão de flo complas omitidas assim, o estudo.

AMAZONAS - Na seção referente ao Tribunal de Justiça:

Art. 54 - Repete o teor do art. 200 da Constituição Federal.

MARANHÃO - Omissa. Justiça:

MATO GROSSO - Nos casos de competência do Tribunal de

Art. 49, n. ${ }^{\circ}$ VII - declarar, pelo voto da maioria de seus membros, a inconstitucionalidade de lei ou ato do Poder Público; Federal.

PARÁ - Art. 62 - Repete o teor do art. 200 da Constituição

PARAÍBA - Na seção referente ao Tribunal de Justiça e aos Juizes de Direito:

Art. 65 - O Tribunal de Justiça só poderá declarar a inconstitucionalidade de lei ou ato do Poder Público, pelo voto de sua maioria absoluta;

RIO GRANDE DO NORTE - Art. 67 - Compete privativamente ao Tribunal de Justiça: declarar, pelo voto da maioria absoluta de seus membros, a inconstitucionalidade de lei ou ato do Poder Público.

RIO DE JANEIRO - Art. 58 - Repete o teor do art. 200 da Constituição Federal.

SERGIPE - Art. 75 - Compete ainda ao Tribunal de Justiça:

e) declarar, pela maioria absoluta de seus membros, a inconstitucionalidade das leis.

ALCIDES DE MENDONGA LIMA

\section{RELATÓRIO E PARECER}

Relator: PAULO BROSSARD DE SOUZA PINTO

A tese que me cabe relatar se intitula - "Competência para. declarar a inconstitucionalidade das leis" - e é de autoria do prof. Alcides Lima, da Faculdade de Direito de Pelotas.

O A. expõe os sistemas judiciário ou não, da sindicância da, constitucionalidade das leis, o primeiro como sendo, em regra, praticado pelas nações americanas, o segundo, geralmente adotado no. continente europeu.

Depois de ressaltar que é antes um dever do que um poder a declaração judicial de inconstitucionalidade, quando esta for manifesta, passa o A. a examinar dispositivos da Const. Fed, e da dos Estados a partir de 1891, pertinentes ao tema sôbre o qual se propôs escrever. E discordando de RUI, e, ao meu aviso, da letra expressa. do Código Supremo de 24 de fevereiro, entende que sòmente em 1934 (art. 179), apareceu disposição expressa que de modo categórico se referisse à prerrogativa judicial da declaração de inconstitucionalidade de leis ou decretos.

Relativamente ao assunto, citando algumas cláusulas das Constituições vigentes nos Estados, no período de 1935-37, põe de manifesto divergências de redação ("juizes e tribunais", usada entre outras pela do R. G. Sul, "poder judiciário", etc.), para concluir que as constituintes estaduais interpretaram diferentemente o art. 179 do Estatuto federal de 1934.

Referindo-se à Const. de Sergipe, diz o A. que ela atribuía, privativamente, à Côrte de Apelação a competência para declarar a inconstitucionalidade de lei. Aqui, entretanto, é tangível o engano do A. O que a Const. sergipana de 16 de julho de 1935 diz em seu art. 81, "b", é que - "compete ainda à Côrte de Apelação: b) declarar definitivamente a inconstitucionalidade das leis, por maioria absoluta da totalidade de seus membros".

Refere após o ilustre A. a norma do art. 96 da Carta de 37, que não diferia, excluido o seu parágrafo, do art. 179 da Constituição revogada e do art. 200 da atual, para propôr a questão fundamental da tese: os juizes singulares, ou de primeira instância, podem declarar inconstitucional uma lei ou um decreto? Ou à luz do art. 200 que reza: "só pelo voto da maioria absoluta dos seus membros poderão os. tribunais declarar a inconstitucionalidade de lei ou de ato do poder público", essa prerrogativa é peculiar aos tribunais em sentido estrito?

Citando as leis de Organização judiciária do R. G. Sul, S. Paulo, Minas, D. Federal, elaboradas no período de vigência da Carta de 37, 
"conclui que elas negavam aos juizes de primeira instância a faculdade de declarar inválidos dispositivos ou atos contraventores da lei maior.

A conclusão a que se chega, entretanto, dos textos citados pelo ilustre jurista, é exatamente a inversa. E é a conclusão que leva o exame das Const. vigentes, conclusão contrária à alcançada pelo A., que entende haver uma exclusão dos juizes de primeira instância na prerrogativa judicial em tela.

Passa, após, o A. a analisar a doutrina e a jurisprudência. E reconhece que esta, inclusive a firmada pelo egrégio Supremo Tribunal, é no sentido de reconhecer que a faculdade de negar cumprimento a um ato, legislativo ou administrativo, tido como inconstitucional, é inerente ao poder judiciário.

Uma única decisão, de 1940, do Tribunal da Bahia, cita o A. em prol de sua tese.

E relativamente à jurisprudência posterior a 1946, refere apenas um caso contra as suas conclusões, o que se compreende porque o trabalho relatado não é recente, tendo sido publicado na Revista Forense, CXXIII, 347-355, de junho de 1949, pois já agora é farta a jurisprudência pelo reconhecimento da competência dos juizes singulares para o fim apontado. Jurisprudência inclusive do Supremo Tribunal.

Relativamente à doutrina diz o A. que há duas correntes: uma que nega tenham, outra que afirma terem os juízes de primeira instância poder, ou dever, de optar pela Const., rejeitando a lei ou o ato dela contraventora.

Entre os desta corrente, acertadamente o A inclui MAXIMILIANO, ESPINOLA e LUCIO DE BITTENCOURT. Entre os vultos que se contariam sustentando a primeira corrente, ressalta o A. as figuras de PONTES DE MIRANDA e de TEMISTOCLES CAVALCANTI.

O insigne PONTES DE MIRANDA, entretanto, é formalmente contrário à conclusão do A. Várias são as suas lições nesse sentido.

Assim, comentando a Carta de 37, explicava que, suscitada questão constitucional, os autos deviam subir à decisão do Tribunal pleno, para que, resolvida ela, voltassem à Câmara ou Turma, e esclarecia: "isso ocorre sempre que não se trata de juiz singular, ou do próprio Tribunal pleno". (Com. Const. 1937. III, 57).

E no IV volume dos seus Com. à Const. de 1946, enuncia o jurisconsulto inadvertidamente invocado pelo A.: "o juiz não tem o arbítrio de deixar de lado a questão constitucional ou as questões constitucionais que as partes ou o Ministério Público levantarem. E' missão sua. E' dever seu". (op. cit. IV, 187).
E há passagem ainda mais concludente, que se lê nos comentários de PONTES às Const. de 1934, 1937 e 1946, respectivamente

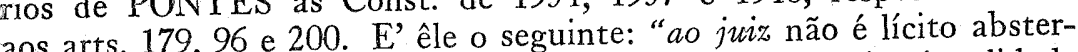
a decidir da defesa fundada na inconstitucionalidade se de conhecer e decidir Const de 34 de lei, ainda que seja o de primeira instancia. (Com. a Const. de 34, II, 551, n. 9; Com. à Const. de 37, III, 52, n. 9; Com. à Const. de 46, TV, 185, n. 4).

TEMISTOCLES CAVALCANTI também não conforta a tese do A e está mal situado na categoria em que foi colocado. "A questão do quorum. O artigo comentado, embora afirmando enfativatáo do quorum. mente que os Iribunais podem duorum mínimo para essas decisóes". (A Const. Fed. Com., IV, 216).

Conclui, por fim, o ilustre jurista, que os juizes singulares não possuem competência para declarar inconstitucional uma lei. Ta prerrogativa caberia apenas aos Tribunais, aos órgãos colegiados do Poder Judiciário.

Entende que se 7 desembargadores do Tribunal do R. G. Sul, em Câmaras Reunidas, ou 5 ministros do Supremo Tribunal, não podem Câna lei - "o que dizer-se (são palavras do declarar incón cérebro e uma só A.), assim, de uma decisão proferida por um só cérobro "ef vontade! Haveria de modo muito mais grave, o perigo dos "efeito maléficos de uma decretação de inconstitucionalidade baseada em simples maioria eventual".

As conclusões da tese são as seguintes: (v. fls.)

$$
\text { *** }
$$

A questão fundamental pode ser proposta nestes têrmos: a competên do judiciário para declarar inconstitucionalidades é atribuída pexplicitamente pelo art. 200 , ou êste apenas contém uma regra reexplicitamente pelo art. gimental, de quorum; endereçada aos orgãos colciado atribuida judiciário, ou a competência aludida está explicitamente atribuida pelo art. 101, III, "b" e "c", como já estivera pelos arts. "b" da mes"e "b" e 60 "a", da Const. de 1891, pelo art. 60 " 1 "," "a" "c" da Const. de ma lei, após a reforma de 26 , pelo art. 76 , III, "b" e "c

34 e pelo art. 101, III, "b" e "c", da Carta de 37?

Data venia, discordo do ilustre professor pelotense para entender com RUI BARBOSA e a unanimidade dos antigos juristas, que sempre entenderam consignar a Const. de 91 (ao contrário da norteamericana e aproveitando a exegese jurisprudencial daquele pais) disposição explícita atributiva ao judiciário da tarefa de fiscalizar, dentro de autos, por solicitação das partes, a constitucionalidade das leis.

23 - R. D. - 2. $\mathrm{V}$ ol 
Entendo, outrossim - e para discordar do eminente professor Alcides Mendonça Lima apelo para o apôio da doutrina e da jurisprudência - entendo que a disposição do art. 200 não é atributiva de competência, mas se trata de regra materialmente regimental, transferida, pela importância dos seus efeitos, ao elenco constitucional.

Com efeito, diz MAXIMILIANO que "os impenitentes apologis tas exclusivos da interpretação filológica, apressaram-se a concluir dos têrmos da regra suprema n. 200 que apenas os pretórios coletivos poderiam declarar inconstitucional uma lei ou um ato executivo". para logo após afirmar positivo: "tudo leva a concluir que o art. 200 só resolve uma questão de quorum; não trata de questão de COM. PETENCIA. A inconstitucionalidade pode, E DEVE, ser declarada logo, NA PRIMEIRA INSTÂNCIA". (Com. III, n. 636, pgs. 263,5).

Atrevo-me a dizer que a própria interpretação filológica não leva a conclusão distinta. O que a Const. diz, claramente, é que os tribu nais decidirão pelo voto da maioria absoluta dos seus membros em tais casos. E' evidente que a regra se endereça aos tribunais porque só êles são colegiados. Para que se entendesse diversamente, seria mister que o dispositivo tivesse esta redação: "só os tribunais, poderão, e pela maioria absoluta de seus membros, declarar a inconstitucionalidade de lei, ou ato do poder público", como deixou exuberantemente provado, em sentença (Rev. For. CXXVIII 549) louvada por AGUIAR DIAS, o juiz LAURO FABRICIO DE MELLO PINTO, de Guarapoava, Est. do Paraná, e na qual se declarava competente, invocando até julgados do Supremo, para conhecer da argüição de inconstitucionalidade levantada contra uma lei.

Depois, como explanou magnificamente o referido magistrado, "além de tudo isso, a própria Constituição federal estabeleceu claramente a atribuição do juiz singular para declarar a inconstitucionalidade, quando estatuíiu que compete ao Supremo Tribunal julgar em recurso extraordinário, as causas decididas em única ou última instância por outros tribunais, ou juizes, quando se contestar a validade de lei, ou atos de govêrno local, em face da Constituição ou de. lei federal. (art. 101, III, C). A errônea interpretação restrita levanta antinomia insolúvel entre os dois textos constitucionais: o do art. 101, III, letra "c", que confere ao juiz singular a apreciação de. lei local em face da Constituição Federal, e o art. 200, que, na verdade, não estabelece senão uma questão de quorum nos pretórios co. letivos". (Rev. cit. pg. 550).

A interpretação sistemática, dest'arte, apenas confirma a cha. mada gramatical ou filológica.

Assim, se dúvida houvesse no tocante ao conteúdo do art. 200 , em face especialmente do que dispõe o 101, III, "c", seria de aplicar-se" a recomendação da boa hermenêutica, segundo a qual, "no caso de. ambigüidade, tôda a constituição deve ser examinada de modo a determinar a significação de alguma parte; e a construção deve ser tal que torne efetivo todo o instrumento e não dê origem a nenhum conflito que possa ser envitado entre suas partes". (AURELINO LEAL. Teoria e Prática da Constituição Federal, 1925, regra II, n. 2, pg. 9, e HENRY CAMPBELL BLACK, Handbook on the Construction and Interpretation of the Laws, 1896, n. 10, pg. 17) "in case of ambiguity, the whole constitution is to be examined in order to determine teh meaning of any part; and the construction is to be such as to give effect to the entire instrument, and not to raise conflict between its parts can be avoided").

Ao demais, é ainda conselho seguro, "se existir ambigüidade que não possa ser esclarecida pela própria Const., pode-se, para determinar sua significação, e fim, recorrer a fatos estranhos, tais como o estado anterior à lei, o mal a ser remediado, as circunstâncias da história contemporânea, ou as discussões da Constituinte". (AURELINO LEAL, op. cit., n. II, 10, pg. 10).

Ora, já antiga lei exigia que pelo menos dez ministros estivessem presentes (dois terços do Tribunal) para que o Supremo Julgasse inválido atos ou decisões de autoridade administrativa (dec. 1939, de 2-8-1908, apud MAXIMILIANO, Com. I, 153, nota 4), tendo a jurisprudência generalizado o preceito a ponto de, por unanimidade, o S. T. F. declarar nulo um acórdão seu embargado, porque uma das partes fundara a sua intenção em preceito constitucional e se deliberara com a presença de menos de dez ministros. (Ac. de 14-6-916, apud MAXIMILIANO, loc. cit.).

E o Supremo Tribunal apenas aceitara as conclusões da doutrina. MAXIMILIANO, comentando o estatuto de 1891, expunha como recomendável o preceito hoje, e desde 1934, incorporado ao texto supremo. (Com., 1929, n. 89).

E o ilustre jurista não inovava, senão trasladava a lição de MARSHALL, de COOLEY, de WILLOUGHBY, de BALDWIN, de WATSON, a lição, enfim, do constitucionalismo norte-americano (Com. I, 153,4, nota 4).

$\mathrm{O}$ que a Const. fez, portanto, foi tornar constitucional, u'a norma que a doutrina, a lei ordinária, o regimento do Supremo Tribunal, já haviam consagrado (CASTRO NUNES, Teoria e Prática do Poder Judiciário, 1943, pg. 599-600, e TEMISTOCLES CAVALCANTI, A Const. Federal Comentada, IV, 216-217).

Forçoso é concluir, dest'arte, que não se alterou "o estado anterior à lei", antes, foi êle expressamente consagrado e serve de pressuposto à atual norma constitucional.

De resto, o elemento histórico também é concludente. "O dispositivo do art. 190. (200, da Const.) do Projeto se aplica indistinta- 
mente ao Supremo Tribunal e aos demais tribunais e juizes do país e a atribuição de declarar a inconstitucionalidade é reconhecida até aos juizes singulares", (JOSE DUARTE, A Const. Brasil. de 1946 III, 368,9) dizia a justificação da emenda que originou o atual art.
200.

A norma dêste é reflexo, até certo ponto, do princípio segundo o qual sòmente em caso de manifesta inconstitucionalidade deva ser ela decretada, inclinando-se o juiz pela validade da lei em caso de dúvida. (BLACK, op. cit., n. 43, pg. 93, MAXIMILIANO, $3 .^{\circ}$ ed., n. ${ }^{\circ}$ 366, pg. 363 da Hermenêutica e Aplicação do Direito).

A exigência de um alto número de votos (Dakota e Ohio exigem a totalidade menos um dos votos dos membros do Tribunal, JOÃO MANGABEIRA e ELOI JOSÉ DA ROCHA, êste interpretando sugestão do Instituto da Ordem dos Advogados do R. G. Sul, preferiam 2/3) não deixa de ser uma aplicação, aos tribunais, do mesmo princípio que deve inspirar a decisão de juizes e membros dos órgãos colegiados, individualmente considerados, quando tenham de julgar da validade de leis em face à Constituição.

Em tôrno à regra apontada se verifica uma coisa rara no mundo jurídico: a unanimidade. "O poder, cometido à justiça, de negar observância às leis inconstitucionais está vinculado à condição de que a inconstitucionalidade seja patente, flagrante, indubitável" (RUI, Com à Const. Fed., VI, 544 e nota 1, pgs. 544 a 546).

Para ser declarada é mister que a inconstitucionalidade seja manifesta, na linguagem da antiga lei 221, de 1894 .

Foi por isso que MANGABEIRA sustentava a conveniência do voto de $2 / 3$ do Tribunal para definitivamente fulminar de inconstitucionalidade uma lei, nos têrmos do ante-projeto do Itamarati. "Evitavam-se, assim, escrevia o eloqüente jurista, as famosas decisões de cinco por quatro, que tanto têm abalado o prestigio da Suprema Côrte Americana. ... Não colhe afirmar que os tribunais só declaram a inconstitucionalidade, quando está fora de qualquer dúvida razoável. Ab initio, não póde haver inconstitucionalidade mais duvidosa do que aquela repelida pela Assembléia, rejeitada pelo Presidente da República, na sanção, e, no Supremo Tribunal, impugnada por cinco dos seus onze Ministros. Dentro da razoabilidade humana, nenhuma dúvida se poderia originar de procedência menos discutível ou se revestir de fôrça mais formidável. E tudo há de ceder, inclusive a lógica e o bom senso, porque um Ministro, juntando-se a uma das metades da Côrte, anulou a outra, dois Poderes eletivos do Estado, que haviam, muita vez, feito e sancionado a lei, para atender aos mais instantes clamores populares, servir aos supremos interêsses do País. Em casos tais, e ainda assim por ficção, a dúvida só se poderia considerar inequívoca, se a inconsti- tucionalidade se pronunciasse por uma grande maioria". (Em tôrno da Constituição, 115).

A regra regimental contida no art. 200. se explica tenha sido constitucionalizada, porque há ainda razões de ordem política que aconselham a exigência de um alto quorum para a delicada tarefa de nulificar leis, negando-lhes aplicação. São várias.

Uma delas visa subtrair o Tribunal do desprestígio, em que incorreria, se tivesse a sua jurisprudência variada de semana a semana, fruto da ausência ou do impedimento de um juiz, que possibilitasse a vitória de uma maioria ocasional.

Ainda há outro aspecto político e jurídico a considerar. E' a necessidade de renovação e adaptação aos novos tempos dos velhos textos, para cuja tarefa são mais aptos os poderes que derivam imediatamente do povo.

Foi o que J. MANGABEIRA expôs magistralmente: "numa democracia, os poderes eletivos, os únicos que répresentam o povo, não devem ter a manifestação de sua vontade consubstanciada na lei, anulada ao sabor de uma maioria efêmera, precária ou ínfima do Supremo Tribunal, Para que a decisão dêsse grande órgão, mereça, em caso de tamanha gravidade, o acatamento da Nação, é preciso que o voto de uma maioria respeitável assegure a todos a certeza de que, dentro da razoabilidade humana, dúvida não pode haver sôbre a juridicidade do julgamento supremo. ... Tal fôrça não terá jamais a decisão por um voto. Diante da dúvida que salteia e divide a própria Côrte, não há de ser ao palpite de uma vontade, ao imprevisto de um acaso, ou ao inopinado de uma surprêsa, que deverá ruír por terra a lei votada e sancionada pelos Poderes eletivos, e que ainda no Tribunal encontrou a quase maioria de seus membros, para sustentá-la e defendế-la. Em casos tais, diante do Tribunal cindido meio a meio, prepondere a lei, oriunda dos Poderes que, eleitos nas urnas, representam a Nação". (op. cit. 117-8).

Assim, entendo que a cláusula n. 200 da Const. federal, e as estaduais que a repetem ou a reproduzem com pequenas alterações, é, materialmente, uma disposição regimental, fixadora de quorum, não da competência.

Esta não deriva dela, mas do art. apontado, e é inerente ao Poder Judiciário, decorre do seu dever precipuo de declarar o direito aplicável à espécie que lhe é submetida.

COOLEY, com a sua autoridade de clássico, expunha: "a missão das côrtes é aplicar a lei da terra às controvérsias suscitadas e perante elas levadas. Sua autoridade é coordenada com a da legislatura, uma não sendo superior à outra; mas cada uma deve mover-se com igual dignidade na esfera que lhe é peculiar. Mas o Poder Judicial, ao determinar qual a lei a aplicar-se em uma controvérsia determina- 
da, pode talvez verificar que a vontade da Legislatura, expressa na lei, e a vontade do povo, traduzida na Constituição, estão em conflito, não podendo ambas permanecer juntas. Em tal caso, como o Poder Legislativo é conferido pela Constituição, é manifesto que o delegado se excedeu na sua autoridade; que o mandatário não se manteve dentro dos limítes de seu mandato. O excesso é por conseguinte ineficaz, e é dever da Côrte reconhecer e fazer efetiva a Constituição como sendo a lei primordial, e pràticamente anular a sanção legislativa, negando-se a fazê-la cumprir. A obrigação de cumprir êste dever, tôda a vez que o conflito se apresente, é imperativo". MAS M. COOLEY, The General Principles of Constitutional Law in the United States of America, 1891, pgs. 151-2: "The business of the courts is, to apply the law of the land in such controversies as may arise and be brought before them. Their authority is co-ordinate with that of the legislature, neither superior nor inferior; but each with equal dignity must move it its appointed sphere. But the judiciary, in seeking to ascertain what the law is which must be applied in any particular controversy, may possibly find that the will of the legislature, as expressed in statute form, and the will of the people, as expressed in the Constitution, are in conflict, and the two cannot stand together. In such a case, as the legislative power is conferred by the Constitution, it is manifest that the delegate has exceeded his authority; the trustee has not kept within the limits of his trust. The excess is therefore inoperative, and it is the duty of the court to recognize and give effect to the Constitution as the paramount law, and, by refusing to enforce the legislative enactment, practically nullify it. The obligation to perform this duty, whenever the conflict appears, is imperative").

E' a mesma e atual lição de MARSHALL: “ consiste expecificamente a alçada e a missão do poder judiciário em declarar a lei. Mas os que lhe adaptam as prescrições aos casos particulares, hão de forçosamente explaná-la, e interpretá-la. Se duas leis se contrariam, aos tribunais incumbe definir-lhes o alcance respectivo. Estando uma lei em antagonismo com a Constituição, e aplicando-se à espécie a Constituição e a lei, de modo que o tribunal haja de resolver a lide em conformidade com a lei, desatendendo à Constituicão, ou de acôrdo com a Constituição, rejeitando a lei, inevitável será eleger, d'entre os dois preceitos opostos, o que dominará o assunto. Isto é da essência do dever judicial". (It is emphatically the province and duty of the judicial department to say what the law is. Those who apply the rule to particular cases, must of necessity expound and interpret that rule. If two laws conflict with each other, the courts must decide on the operation of each. So if a law be in opposition to the Constitution; if both the law and the Constitution apply to a particular case, so that the court must either decide that case conkormably to the law, disregarding the Constitution, or conformably to the Constitution, disregarding the law, the court must determine wicht of these conflicting rules governs the case. This is of the very ressence of judicial duty." Cases and Materials on Constitutional Law by Henry ROTTSCHAEFER, 1948, pg. 11 A passagem citada é do "case" Marbury v. Madison, e a tradução acima é de RUI, Atos Inconst., 1893, pgs. 52-3).

$$
\text { *** } *
$$

Reconhecendo que é conveniente uma questão de constitucionaMidade não deva morrer, pela passagem em julgado da sentença que a declarar, em primeira instância, muito embora não seja isso uma calamidade porque o decreto judicial opera entre partes e não revoga a lei, sou de parecer que:

a) partindo do pressuposto de que o juiz singular tem competência para declarar a inconstitucionalidade de lei ou ato do poder público, porque ela é inerente à função judicial;

ib) é recomendável, entretanto, que o juiz, à semelhança de outros casos previstos em lei (c. proc. civ., art. 822, seu parágrafo e itens) venha a apelar ex-ofício da sua sentença, quando esta declarar inconstitucional lei ou decreto, proporcionando assim, necessàriamente, um novo exame da questão por um órgão judiciário de instância superior, independente de recurso da parte.

E se a Comissão da 6. ${ }^{\mathrm{a}}$ Secção do Congresso aceitar o parecer e a sua sugestão final, poderia recomendar ao plenário do Congresso lembrasse ao poder competente a elaboração de lei que a consagrasse.

Sala das sessões, 14 de agosto de 1950.

Camilo Martins Costa - presidente

Paulo Brossard de Souza Pinto - relator

Darcy Azambuja

João Abreu

Fay de Azevedo

Francisco Juruema

Francisco Machado Vila 


\section{DEBATES EM PLENÁRIO}

O SR. PRESIDENTE - José Salgado Martins - Na ausência eventual do sr. $10^{\circ}$ Vice-Presidente, cabe-me a honra de presidir os. trabalhos desta sessão do Congresso Jurídico.

Não havendo expediente a divulgar, passaremos à ordem do dia, na qual figuram vários trabalhos que serão objeto de relatórior e debate.

O primeiro trabalho que se encontra sôbre a Mesa versa sôbre a competência para declarar a inconstitucionalidade das leis. E' autor dêste trabalho o professor Alcides de Mendonça Lima, e relator o dr. Paulo Brossard de Souza Pinto, a quem tenho o prazer de conceder a palavra.

O SR. PAULO BROSSARD DE SOUZA PINTO - Sr. Presidente, senhores Congressistas, o eminente professor Alcides de Mendonça Lima, apresentou a tese intitulada "Competência para de-clarar a inconstitucionalidade das leis".

\section{(Lê o relatório e as conclusões da tese)}

O parecer e sugestões foram aprovados pela unanimidade da $6 .^{\text {a }}$ Comissão.

Era o que tinha à dizer, sr. Presidente. (Palmas).

O SR. PRESIDENTE - Vamos, então, submeter a debate a tese da competência para declarar a inconstitucionalidade das leis. Concederei a palavra a quem dela quiser fazer uso.

O SR. ALCIDES DE MENDONÇA LIMA - Peço a palavra. sr. Presidente.

O SR. PRESIDENTE - Tem a palavra o ilustre professor.

O SR. ALCIDES DE MENDONÇA LIMA - Sr. Presidente, eminentes colegas Congressistas:

O belíssimo trabalho que acabamos de ouvir, é, sem dúvida, uma das recomendações do talento, do brilho e do esfôrço do seu autor, que é um dos expoentes, já não direi da sua geração, mas, das letras jurídicas do nosso Estado.

Entretanto, como autor da modesta tese apresentada a êste conclave, permito-me oferecer algumas considerações em defesa do ponto de vista que sustentei.

Quero, inicialmente, acentuar que não nego ao juiz de primeira instância, como a nenhuma parcela do Poder Judiciário, a faculdade, o dever mesmo, como acentuei em meu trabalho, inerente ao Poder Judiciário, de declarar a inconstitucionalidade das leis, de acôrdo com a célebre doutrina norte-americana.
Isto, aliás, eu \& afirmo, expressamente, na conclusão da tese. E" inerente ao Poder Judiciário e deve competir-lhe a declaração da inconstitucionalidade das leis ou dos atos do poder público.

Entretanto, se é inerente essa faculdade, se êsse dever se impóe. ao Poder Judiciário, entendo que cada Estado, cada povo, de acôrdo com suas condições peculiares, em conformidade com suas condições jurídico-sociais e políticas, pode subtrair essa competência de alguma. ou de algumas parcelas do Poder Judiciário, para atribuí-la apenas a outras.

Quando sob a Constituição de 1891, segundo o meu ponto de vista, não havia uma determinação expressa da competência a um certo órgão, aí sim, seria ampliar a faculdade outorgada ao Poder Judiciário, desde o mais humilde juiz até o mais alto tribunal.

Todavia, se desde 1934, as Constituições entenderam de atribuir aos tribunais, órgãos colegiais, esta competência, não se pode atribuir esta competência ao juiz singular?

Respondo com as próprias palavras de João Mangabeira, transcritas na minha tese e no parecer: "Numa democracia os poderes. eletivos, únicos representantes do povo, não devem ter a manifestacão da sua vontade, consubstanciada na lei, anulada ao sabor de uma maioria efêmera do Superior Tribunal".

Por conseqüência, dentro do tribunal não se admite que um juiz possa apreciar os atos do Poder Legislativo, como se admitir, então, que uma lei possa ser inquinada de inconstitucional, pela vontade de um magistrado, podendo esta lei ter auxílio e fôrça para ser executada, e, ser esta lei julgada inconstitucional e passar em julgado?

Como poderemos atribuir esta alta prerrogativa a um juiz, ainda inferior na carreira judiciária, por maior mérito pessoal que apresente, êste poder de sustentar, com o pêso da sua autoridade de membro do Poder Judiciário, que esta lei é inconstitucional? Que êsse juiz, sem mais exame ou estudo, declare inconstitucional essa lei e passando em julgado essa sentença vá obter a colaboração do Poder Executivo, para impor, pela fôrça, a sua vontade?

Se uma questão dêsse quilate pudesse ficar ao sabor de uma só vontade, de um só juiz de uma pequena comarca, de um município ainda de poucos recursos culturais, para imprimir uma pecha de êrro ao Poder Legislativo e Poder Executivo, essa sentença estaria corroendo a própria ordem jurídica do país.

E' interessante observar, senhores Congressistas, nos diversos. Estados do país, a interpretação que os legisladores regionais deram a esta norma da Constituicão Federal, já não digo de 1946, mas, desde 1934, quando pela primeira vez apareceu, expressamente, nos nossos estatutos fundamentais:

As diversas Constituições que nasceram sob a égide da de 1934 , de efêmera vigência, algumas delas, como as do Amazonas, de Goiaz, 
de Mato Grosso e de Alagôas, incluiram a matéria como atribui‘ção própria da Côrte de Apelação.

E' interessante observar as leis de organização judiciária que nasceram sob a égide da Constituição de 1937, na ausência de nova Constituições Estaduais, inclusive a do Distrito Federal - e ịsto é importante para a tese, porque foram os mesmos legisladores, possívelmente as mesmas pessoas físicas que elaboraram o ato discricionário de 1937, e a lei de organização judiciária do Distrito Federal, - pois atribuiram esta competência apenas ao Tribunal de Apelação do Distrito Federal.

Durante a Constituição de 1946, já na vigência de nossa atual constituição, as Constituições Estaduais seguem, de modo geral, o mesmo sistema. Coligí uma por uma das Constituições, e elas exatamente assentam êste ponto de vista. Algumas delas atribuem esta competência aos tribunais colegiados do Poder Judiciário.

O que a tese propõe é justamente que haja um recurso ex-ofício, para que a sentença não subsista por si, para que não passe em julgado.

Não se deve argumentar que sejam questões apenas entre partes, que as partes se conformando, não havendo recorrido, se submeteram ao julgamento, mas, aqui, a constitucionalidade ou não da lei não é problema que interesse eminentemente às partes - pode interessar securdàriámente às partes - o interêsse é mais fundamentalmente da sociedade em geral, porque ela vai corroendo, pouco a poco, aquela lei.

Se cada juiz das diversas comarcas vai dizendo que a lei é inconstitucional, aquela lei vai ficando afetada, e é frizante que o Poder Executivo poderá ser invocado para dar seu beneplácito à decisão do juiz de que houve falha do Poder Legislativo e do Poder Executivo, na sua elaboração.

E' interessante, também, um argumento que nos Juízos do Trabalho, é função inerente do Ministro do Trabalho a função normativa. Nem por ser normativa é atributo de tôda a Justiça do Trabalho, porque é subtraida a Junta de Conciliação.

Não afirmo que o juiz deva aplicar a lei inconstitucional; êle deixará de aplicá-la. Basta que um juiz mais inferior da carreira, de um lugar menor do Estado, entender na sua alta sabedoria ou na sua completa ignorância, que uma lei é inconstitucional, ela subirá ao órgão superior, que verá se a lei é ou não inconstitucional.

Lúcio Bitencourt, que se filiou à corrente vencedora - pois eu confesso que a corrente onde me situei não é a vencedora - no seu livro especializado, na sua monografia, cita a hipótese de que deve existir recurso ex-ofício para isso, mas entende que no momento da sentença passar em julgado, se não fôr oposto recurso, outra é a situação.

Se um juiz dêsse quilate sente e acha necessária a existência do recurso ex-ofício, pergunto, por que esta liberalidade, esta tolerância com um juiz de primeira entrância, quando os tribunais colegiados não podem decretar a inconstitucionalidade de uma lei? Por que motivo um agravo chega a uma câmara de três membros e esta não pode declarar a inconstitucionalidade da lei, e mesmo sem haver uma regra ou norma que o determine, este processo deve ser remetido ao tribunal pleno? O juiz não pode aplicar e remeter os feitos ao tribunal pleno? Por que?

$\mathrm{Na}$ ação rescisória, se não há quorum em plenário, não se permite que o tribunal ou Câmara Civel reunida, numa ação rescisória, decrete a inconstitucionalidade de uma lei. Então devam os feitos subir ao tribunal pleno?

Onde a regra estabelecendo a remessa para o tribunal pleno? Ela é apenas a decorrência de um princípio. Mas, o princípio deve abranger o juiz de primeira entrância.

$\mathrm{Na}$ primeira lei de organização judiciária, nascida sob a égide da Constituição de 1937, estabeleceu-se que deveriam ser remetidos para o Tribunal de Apelação, cabendo aos juizes declarar a inconstitucionalidade das leis.

Por conseguinte, se uma própria parcela do tribunal, e digo mais, se às próprias turmas isoladas do Supremo Tribunal Federal se nega êsse direito, porque se atribuir mais direito a um juiz singular, que pelo seu parco tirocínio, e sobretudo pela sua ausência da autoridade que decorre de sua função singular, não tem autoridade paar atirar ao Poder Legislativo ou ao Poder Executivo a pecha de haverem violado a Constituição, se atribui essa competência?

Por êsses fundamentos, se bem que não haja colisão entre o parecer e a tese, apenas partem de pressupostos diferentes, mas chegam, de modo geral, à mesma conclusão, mas, por uma questão doutrinária, de ordem jurídica, entendo que o ponto de vista da tese é aquêle que deixei amparado na opinião de autores que a sufragam, como Themístocles Cavalcanti - em que pese o ponto de vista do relator - e Pedro Calmon, entendo que a tese deve ser aprovada pelo Congresso, porquanto a sua conclusão é que melhor atende o problema de ordem legal, constitucional, política e social. (Palmas).

O SR. PRESIDENTE - Continua em debate a tese.

O SR. PAULO BROSSARD DE SOUZA PINTO - Peço a palavra, sr. Presidente.

O SR. PRESIDENTE - Tem a palavra o relator. 
O SR. PAULO BROSSARD DE SOUZA PINTO - Depois da brilhante sustentação do eminente Congressista professor Alcides de Mendonça Lima, na qualidade de relator do seu trabalho, entendo ter a obrigação de sustentar o parecer, nos têrmos em que êle se choca com as conclusões do trabalho.

Deixando de lado, o pressuposto da controvérsia, que para o autor da tese é que o juiz singular não pode declarar insconstitucional uma lei, devendo remeter os autos a superior instância, para que a questão preliminarmente seja decidida pelo tribunal, e depois, então, baixados os autos, fazer continuar o feito, pressuposto que, segundo o parecer, - o juiz pode, mais do que pode, possui o dever e, portanto deve declarar a inconstitucionalidade, evidentemente nos casos em que ela fôr manifesta - há alguns aspectos muito interessantes e que, parece, não devem passar despercebidos.

E' que, segundo a sugestão do eminente autor da tese, suscitada uma questão da inconstitucionalidade num feito, o juiz, imediatamente, deveria fazer sustar a sua marcha e subir os autos ao tribunal, para só depois que êste julgasse a lei, não a questão, continuasse em primeira instância o feito.

O eminente autor, que é professor de Direito Judiciário Civil, deve ter percebido, nêste momento, que sua sugestão se choca, frontalmente, com um dos princípios fundamentais do moderno processo civil - o princípio da economia processual. Temos, assim, um feito cindido, que sobe ao julgamento do Tribunal, para depois, vir a ser julgado em primeira instância.

O SR. MOZART RUSSOMANO - Peço licença a V. Excia. para dizer que o princípio da economia processual está resguardado
na tese.

O SR. PAULO BROSSARD DE SOUZA PINTO - Mas, neste caso, se respeite, em primeiro lugar, a Constituição da República, que obriga o juiz a decidir os casos. .

O SR. ALCIDES DE MENDONÇA LIMA (interrompendo) Julgando o ato inconstitucional, o jừ não entra no mérito. Não julga o caso.

O SR. PAULO BROSSARD DE SOUZA PINTO - Neste caso, deixa de cumprir com o dispositivo expresso do Código de Processo, que já figurava na Constituição de 1934, segundo o qual é dever do juiz julgar todos os casos que the forem regularmente atribuidos.

O SR. ALCIDES DE MENDONÇA LIMA - Vão os autos ao tribunal. Otribunal julga que na verdade a lei é inconstitucional, e todo o trabalho de julgamento do mérito está perdido.

O SR. MOZART RUSSOMANO - A questão da economia processual é que me parece ficou deslocada por êste detalhe: se a recurso ex-ofício visa exatamente fazer com que a questão preliminar da inconstitucionabilidade seja apreciada pelo tribunal, poderia ser então julgada "prima facie".

O SR. PAULO BROSSARD DE SOUZA PINTO - Lembro que ocorreria uma decisão em tese, à semelhança do atual sistema italiano, que de modo algum é o nosso. Permito-me observar que se o Tribunal examina a questão posteriormente é por uma razão mais que intuitiva e compreensível... De resto, julga a questão em si e não a lei

Mas, o autor, invocando João Mangabeira, na passagem que se refere à conveniência que os tribunais decidam sempre por dois terços, e não por maioria absoluta, comparou o julgamento dos tribunais ao julgamento do juiz singular. Evidentemente, a norma é recomendável...

O SR. MOZART RUSSOMANO - Eu desejaria abrir um parêntèsis, e interromperia para pedir um esclarecimento. Como justificaria o nobre relator a circunstância de uma Câmara do Tribunal não poder declarar inconstitucional uma lei, podendo, entretanto, fazê-lo um juiz singular em primeira instância?

O SR. PAULO BROSSARD DE SOUZA PINTO - Não existe nenhum conflito, por isso que a Câmara não é órgão judiciário de 2. ${ }^{\mathrm{a}}$ instância. O órgão judiciário de $2 .^{\mathrm{a}}$ instância é o tribunal.

O SR. CAMILO MARTINS COSTA - A Câmara é uma entidade fracionária.

O SR. ALCIDES DE MENDONÇA LIMA - E' o tribunal ou não é o tribunal que se manifesta? Não foi o tribunal de Justiça? E' uma Câmara?

O SR. PAULO BROSSARD DE SOUZA PINTO - Nos casos ordinários? Evidentemente, há obediência à lei de organização judiciária.

Mas, dizia eu que a norma se aplica, evidentemente, aos tribunais, porque haveria o risco de tribunais que funcionassem com cinco membros e declarassem a inconstitucionalidade de uma lei, e no ida seguinte, seis, sete e oito juízes a declarassem constitucional. Teríamos uma jurisprudência oscilante em assuntos dessa natureza, o que reverteria em desprestígio do Poder Judiciário, quando se sabe que êsse julgamento supremo deve ser aplicado apenas nos casos de manifesta inconstitucionalidade.

Êste perigo não existe quanto ao juiz de primsira instância, porque não existe possibilidade do fracionamento da opinião

O SR. CAMILO MARTINS COSTA - O juiz é sempre pleno. O juiz é sempre uniforme, vamos dizer assim.

O SR. PAULO BROSSARD DE SOUZA PINTO - E mais: se a decisão passada em julgado, mesmo que seja de um juiz da mais 
modesta entrância, desde que sua sentença tenha passado em julgado, vale tanto quanto um acórdão uniforme do Supremo Tribunal. E' uma decisão do Poder Judiciário.

O SR. ALCIDES DE MENDONÇA LIMA - Daí o perigo de até poder vir em auxílio do Poder Executivo.

O SR. PAULO BROSSARD DE SOUZA PINTO - Por isso concluíu a Comissão que era conveniente que uma questão dessa relevância não se encerrasse em primeira instância, embora não fosse isso uma calamidade, porque a lei continuaria de pé, operando a sentença apenas entre as partes.

E' o mesmo principio que inspirou a sugestão do sr. Lúcio Bittencourt, invocado e citado pelo ilustre autor da tese, e que se não. foi sustentado pelo parecer, poderia ter sido feito, porque consagrou, exatamente, a opinião do parecer, de que é conveniente que um exame dessa gravidade seja reestudado em segunda instância, onde se presume que os juízes dos tribunais, pela sua experiência e cultura, tenham visão mais perfeita e aguda do problema e possam melhor decidí-lo presnção que é relativa, porque a sentença de primeira instância pode ser melhor lançada e julgar melhor que um acórdão do Tribunal de Justica.

O SR. ALCIDES DE MENDONÇA LIMA - Por conseguinte, pela própria conclusão do parecer achando conveniente have recurso ex-ofício, se verifica que não se dá importância vital, decisiva à sentença do juiz. Estamos plenamente de acôrdo. Não nego que o juiz deva declarar a inconstitucionalidade da lei. Apenas entendo que deva o caso ser remetido chegou a essa mesma conclusão. Estou vendo, portanto, que não divergimos. Longe de mim dizer que o juiz não deve declarar lei inconstitucional. Apenas não deve passar em julgado sem exame do tribunal superior. A comissão também entende que decisão do juiz não deve passar em julgado, tem também obrigação precípua de interpor recurso ex-ofício

O SR. PAULO BROSSARD DE SOUZA PINTO - Continuando, queria chamar a atenção para um ponto invocado pelo ilustre autor, e que é relativo dispositivos das Constituições Estaduais e leis de organização judiciária, e que o autor interpreta daduais maneira que ao artigo 200, quando na minha opinião êsses dispositivos se referem sempre aos tribunais, traçando norma apenas aos tribunais e não se referindo genèricamente ao Poder Judiciário, abarcando portanto o juiz singular.

O SR. ALCIDES DE MENDONCA LIMA - E que diz V. Excia. da Constituição do Paraná, que rezava: "Compete privaticamente ao tribunal de justiça..."

O SR. PAULO BROSSARD DE SOUZA PINTO - Poderia entender, em face do argumento que a interpretação sistemática ofe- rece, que era o tribunal de justiça na plenitude de sua composição, e não no fracionamento da suas câmaras ou turmas.

Mas, há outro argumento de que não lancei mão, evidentemente, porque o tema é muito vasto. E' que há uma norma de hermenêutica constitucional segundo a qual a construção de um dispositivo de uma determinada lei - seja ordinária, seja constitucional, - deve vigorar ainda se referindo à nova lei ou nova Constituição, quando o novo diploma legal reproduz, sem variação sensível, o dispositivo anterior.

Neste particular, a elaboração jurisprudencial do nosso país, pràticamente, é uniforme. $\mathrm{O}$ ilustre autor e pesquisador citou um acórdão do tribunal da Bahia em sentido contrário, mas, desde 1934 existe êste dispositivo nas nossas leis fundamentais e tem tido interpretação uniforme como uma regra de quorum e não como uma regra atributiva de competência.

Ainda há outra razão a ponderar, para fixar a bôa inteligência do artigo 200 da lei magna da República. E' que uma decisão definitiva do Supremo Tribunal Federal pode provocar uma manifestação política de natureza legislativa, do Senado Federal. E por isso, é conveniente que essa decisão, que pode provocar uma manifestação de um dos ramos do Poder Legislativo, seja tomada por uma maioria sólida, significativa, convincente e não seja o Senado Federal solicitado a suspender a execução da lei, por reflexo de julgaldos passsageiros, oclasionais, que reflitam uma opinião va* riável, não uniforme, e não assentada do Supremo Tribunal.

Esta é uma consideração que me parece também deva ser feita para que se possa medir a exata inteligência do art. 200 da Constituição.

A dúvida, a controvérsia, se resume, assim, na fixação da inteligência dêste artigo 200. Se é êle uma regra de competência ou se é regra fixadora de quorum. Apenas isto, sr. Presidente. (Palmas).

O SR. PRESIDENTE - Serão submetidas à votação as conclusões do parecer, aprovadas pela $6{ }^{\text {a }}$ Comissão do Congresso.

As conclusões podem ser assim enunciadas: "1. O juiz singular tem competência para declarar a inconstitucionaldade de leis ou atos do poder público, porque ela é inerente à função do juiz; 2. é recomendável, entretanto, que o juiz singular, à semelhança de outros casos previstos em lei - Código de Processo Civil, artigo 222 em seus vários ítens - venha apelar, ex-ofício de sua sentenca, quando esta declarar inconstitucional lei ou decreto, proporcionando novo exame da questão, por órgão judiciário de instância superior, independente do rceurso das partes".

Os srs. Congressistas que as aprovam, queiram ter a bondade de permanecer sentados.

Aprovadas. (Palmas). 